\title{
Unconventional Gas Resources in the Paleozoic of Central Europe
}

\author{
R. Littke ${ }^{1 *}$, B. Krooss', A.K. Uffmann', H.-M. Schulz ${ }^{2}$ and B. Horsfield ${ }^{2}$ \\ 1 Institute of Geology and Geochemistry of Petroleum and Coal, RWTH Aachen University, Lochnerstr. 4-20, 52056 Aachen - Germany \\ 2 GFZ German Research Centre for Geosciences, Telegrafenberg, 14473 Potsdam - Germany \\ e-mail: littke@lek.rwth-aachen.de - krooss@lek.rwth-aachen.de - uffmann@lek.rwth-aachen.de - schulzhm@gfz-potsdam.de - hors@gfz-potsdam.de \\ * Corresponding author
}

\begin{abstract}
Résumé - Ressources de gaz non conventionnels dans le Paléozoïque de l'Europe Centrale Alors que l'extraction du gaz naturel des gisements non conventionnels a fortement augmenté ces dernières dizaines d'années, un large potentiel de ressources reste inexploré dans les couches paléozoïques de l'Europe Centrale. Cet article présente, pour cette région, quelques aspects importants de la géologie des grès de faible perméabilité (tight gas sands), des gaz de schiste (gas shales) et du gaz de houille (coalbed methane, CBM). Les grès de faible perméabilité se trouvent surtout parmi les couches permiennes (Rotliegend) aux Pays-Bas et dans le nord de l'Allemagne, mais aussi dans les couches du Carbonifère supérieur. La production est déjà active dans quelques-uns de ces réservoirs. Pour l'avenir, le développement dépendra principalement de l'amélioration de la compréhension du gaz en place et de la distribution régionale de la porosité et la perméabilité qui, d'ailleurs, dépendent du faciès lithologique et la diagénèse. La recherche de gaz dans les roches argileuses, par contre, vient juste de commencer. Les roches argileuses mésozoïques dans le sud du bassin de Basse-Saxe (Lower Saxony Basin) sont des objets d'exploration prioritaire à cause de leur épaisseur, de leur maturité et de leur teneur en matière organique. Mais il existe d'autres séries intéressantes dans le carbonifère inférieur et des couches plus anciennes. Actuellement, un projet de recherche international vise à acquérir des données géologiques sur ces systèmes. La recherche du gaz de houille (CBM) a commencé dans la bassin de la Ruhr il y a une vingtaine d'années, mais avec un succès très limité à cause de faibles débits de gaz. En revanche, le captage de grisou des mines de charbon abandonnées a fourni de considérables quantités de gaz. De par la multitude des filons houillers et des conditions de maturité et de teneurs en gaz favorables, il existe dans cette région un potentiel considérable de gaz de houille.
\end{abstract}

\footnotetext{
Abstract - Unconventional Gas Resources in the Paleozoic of Central Europe - Whereas gas production from unconventional reserves has greatly increased over the past decades, there is still a largely unexplored potential in the Paleozoic of Central Europe. For this area, the paper summarizes some important aspects of the geology of tight sandstone gas reservoirs, gas shales and coalbed methane. Tight sandstones with low permeabilities are especially present in the Permian (Rotliegend Formation) of The Netherlands and northern Germany, but also in the underlying Carboniferous. There is already active production from some of these reservoirs. Further development greatly depends on understanding of gas charge as well as the regional distribution of porosity and permeability which in turn depend on facies and diagenesis. In contrast exploration for gas shales is just at the very beginning. Whereas Mesozoic shales in the southern Lower Saxony Basin have to be regarded as prime targets due to thickness, maturity and organic matter content, there are additional targets in the Mississippian, but also in older rocks. Currently an international gas shale research programme (Gas shales in Europe, GASH) gathers relevant data for
} 


\begin{abstract}
these units. Coalbed methane exploration started already about 20 years ago in the Ruhr Basin, but was not successful at that time due to small flow rates. On the other hand, production from abandoned coal mines provided substantial amounts of gas. Due to the abundance of coal seams and the suitable maturity conditions and gas contents, there is a high potential for future substantial coalbed methane in the area.
\end{abstract}

\section{INTRODUCTION}

World gas consumption has steadily increased over the past decades leading to a depletion of conventional gas reserves. In future gas supply can only be maintained if additional gas resources are utilized. In this context, gas production from unconventional reserves has substantially increased in recent years, especially in the USA (BGR, 2009). Such unconventional reserves include tight, gas-filled sandstones, coalbed methane and gas-filled shale. These reservoirs can be economically productive, but usually only after stimulation of the wells. Whereas conventional gas reservoirs are buoyancy-dominated, occurring as discrete accumulations in structural and/or stratigraphic traps, unconventional resources are not necessarily buoyancy-dominated (Law and Curtis, 2002). This does not only hold true for gas shales and coalbed methane (Cook, 2003), but also for tight gas sandstones (Shanley et al., 2004).

Current concepts for the exploration of up to now inaccessible or uneconomical gas resources show three tendencies:

- the exploration of very deep and/or very tight (low permeability) sandstones, which are mainly filled with unconventional gas ("tight gas"; "deep gas");

- increased exploration and production from extensive deposits of gas-bearing shales and coals, which are at the same time source and reservoir rock for the gas;

- a growing importance of microbially generated, near-surface gas, both in conventional reservoirs and in the form of gas hydrates in continental shelf areas. In addition in situ coal gasification may become an option for the future.

The Central European Basin system consists of several sub-basins (Fig. 1) and contains a large number of Paleozoic gas fields extending from the North Sea through The Netherlands and Germany to Poland (Gaupp et al., 2008; Lokhorst et al., 1998). The by far largest of these structures is the giant Groningen gas field in the northeast of the Netherlands (south of well Manslagt 1 in Fig. 1). Reservoirs are mainly of Permian age, but Carboniferous (and Triassic) fields exist as well. Chemical composition of the gases in the Paleozoic is highly heterogeneous.

Paleozoic rocks of the Central European Basin system also contain numerous unconventional gas resources. These include coalbed methane (CBM) within the coal-bearing Pennsylvanian sequence, organic-rich shales in the Mississippian (Lower Carboniferous) and possibly also in the Pennsylvanian and Pre-Carboniferous as well as tight gas sandstones in the Upper Permian (Rotliegend) and
Pennsylvanian. These different gas resources differ in (average) Total Organic Carbon (TOC) content, permeability and pore size distribution (Fig. 2, 3).

Coals have generally very high TOC contents $(>50 \%)$ and act as source and reservoir rocks for gas (Fig. 2; Levine, 1991; Littke and Leythaeuser, 1993). Permeabilities are variable, depending on abundance, connectivity and aperture of microfractures (cleats; cf. Laubach, 1998). Pore sizes distribution of coals is characterized by a predominance of nanometer and sub-nanometer pores (Fig. 3; Prinz and Littke, 2005), but large pores are also abundant. One prominent example for CBM production from Pennsylvanian coals is the Black Warrior Basin in the USA (Pashin, 2004), where production occurs mainly from medium volatile bituminous coals.

Gas shales also have high TOC values (up to 30\%) and act both as source rocks, reservoirs and traps for hydrocarbons (Hamblin, 2006). Many of these so-called shales are rich in carbonate or quartz, i.e. they can be regarded as marlstones or siliceous shales. Aside from the richness in TOC, these shale systems differ considerably in mineralogy, maturity, kerogen type, depth and natural fractures. Permeabilities are usually in the nanodarcy range (Fig. 2; Hildenbrand, 2003); therefore sophisticated production technology is a prerequisite for economic development. One prominent Paleozoic example is the Barnett shale in Texas, USA (Hickey and Henk, 2007; Hill et al., 2007) and there are several other productive Palezoic gas shales in the US (e.g. Woodford Shale, Marcellus Shale). Pore radii are usually in the nanometer range (Fig. 3) similar to other claystones, shales and marlstones (Hildenbrand, 2003).

The physical sorption of gas on or within the organic matter is a specific feature and a controlling mechanism in coals and probably also in gas shales (Krooss et al., 2010). Depending on the prevailing subsurface conditions the major portion of the gas does not reside in the free pore space but in the adsorbed state. The relative fractions of free and sorbed gas are controlled by pressure, temperature, organic matter content and composition as well as porosity and water content. Due to its exothermic nature, the importance of sorption will decrease with increasing reservoir temperature, e.g. in deep hot reservoirs. Effects such as swelling or shrinkage of the organic matter due to uptake or release of gas add to the complexity of fluid (gas/water) transport processes in these lithotypes. It has been documented by numerous studies that the sorption properties of coals vary systematically with rank and maceral composition (Hildenbrand et al., 2006 and references therein), and this holds also for the dispersed organic matter in gas shales. 


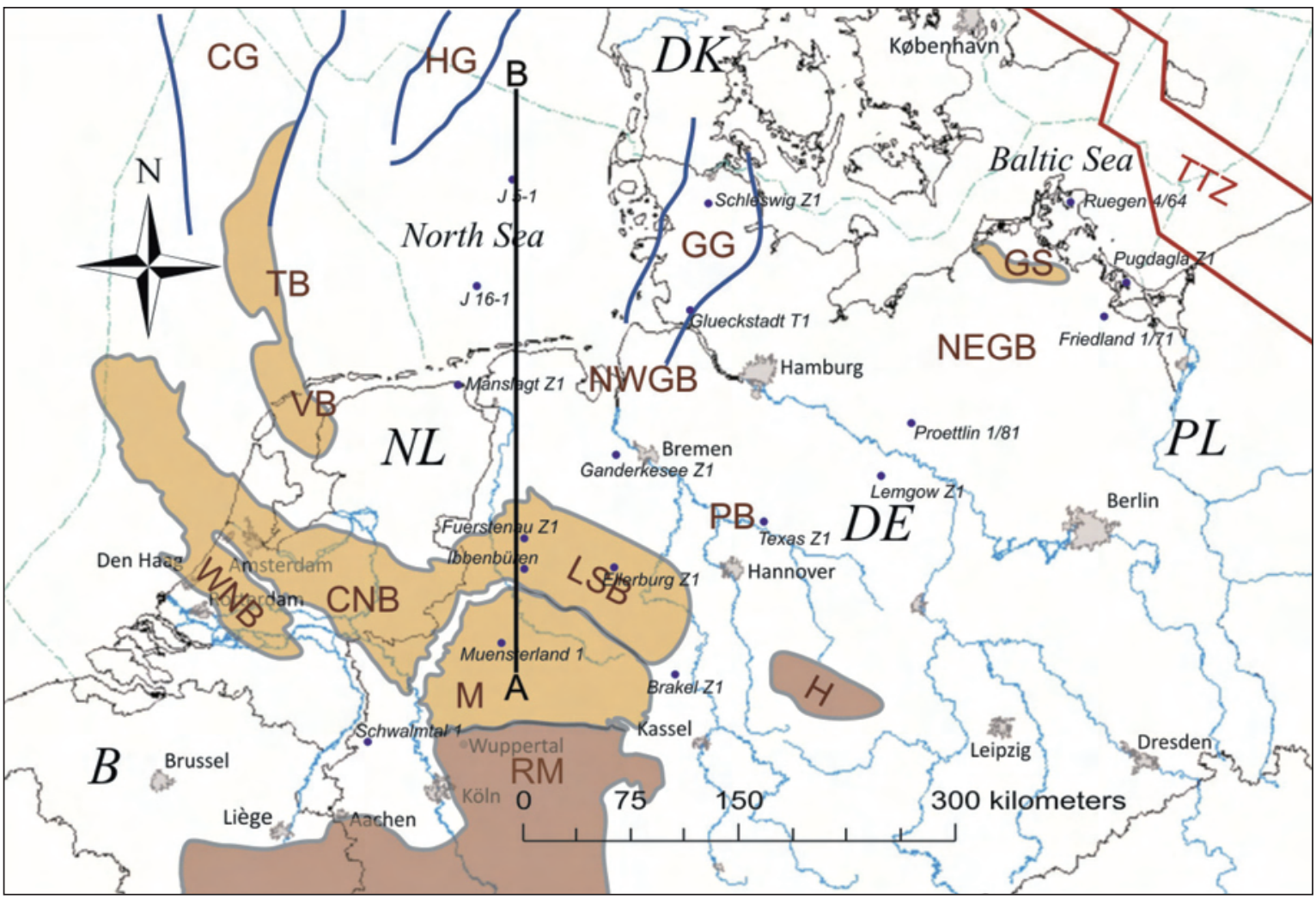

Figure 1

Map showing several sub-basins of the Central European Basin System with cities for orientation (modified from Voigt et al., 2008). For orientation, some important wells are shown (in italics). NL: Netherlands, B: Belgium, DE: Germany, DK: Denmark, Pl: Poland. Some uplifted areas are shown in dark grey shades: RM: Rhenish Massif, H: Harz, M: Münsterland Basin/Ruhr Basin, LSB: Lower Saxony Basin, WNB: West Netherlands Basin, CNB: Central Netherlands Basin, VB: Vlieland Basin, TB: Terschelling Basin, GS: Grimmen Swell. Other basin structures include Central Graben (CG), Horn Graben (HG), Glückstadt Graben (GG), Northwest German Basin (NWGB), Northeast German Basin (NEGB), and the Tesseire-Tornquist Zone (TTZ). Line A-B indicates the position of the cross section shown in Figure 7.

Sorptive storage capacity of coals and organic matter, the key thermodynamic feature, is commonly expressed in terms of excess sorption isotherms measured at temperature and pressure conditions corresponding to those of the reservoirs. High-pressure sorption studies on European coals have been conducted by Gaschnitz (2000), Prinz (2004), Krooss et al. (2002) and others. Figure 4 shows methane sorption isotherms of two coal samples, an anthracite and a medium volatile bituminous coal, and a gas shale measured at 45 and $75^{\circ} \mathrm{C}$, respectively, in the dry state. The data are normalized to the Total Organic Carbon contents (TOC) of the samples. This diagram illustrates the range of sorption capacities encountered in natural coals and carbonaceous rocks. Evidently the gas shale exhibits TOC-normalized sorption capacities approaching those of anthracite.

Recent studies indicate that, rather than the composition and rank of the organic matter, water content has a dominant or even overriding effect on the gas storage capacity of coals and gas shales (Joubert et al., 1974; Hildenbrand et al., 2006). To account for this effect and arrive at more realistic values for sorption capacities, sorption measurements are increasingly performed on moisture-equilibrated samples. The dramatic influence of water content on methane storage capacity of coals is illustrated in Figure 5. The methane sorption capacity of the moisture-equilibrated coal is only in the order of $30 \%$ of the sorption capacity of the dry sample. Usually the sorption capacity of the "as received" coals lies between these two values. These findings indicate that reliable information on the in situ moisture content of coal seams and shale gas systems is crucial for the estimation of reservoir capacities and resource potentials.

Coals and gas shale systems are frequently under-saturated with respect to their total gas storage capacity. The actual saturation state depends on the geologic evolution of the system and the gas generation and migration/dismigration history. Up to now this evolution is hardly predictable and essentially 


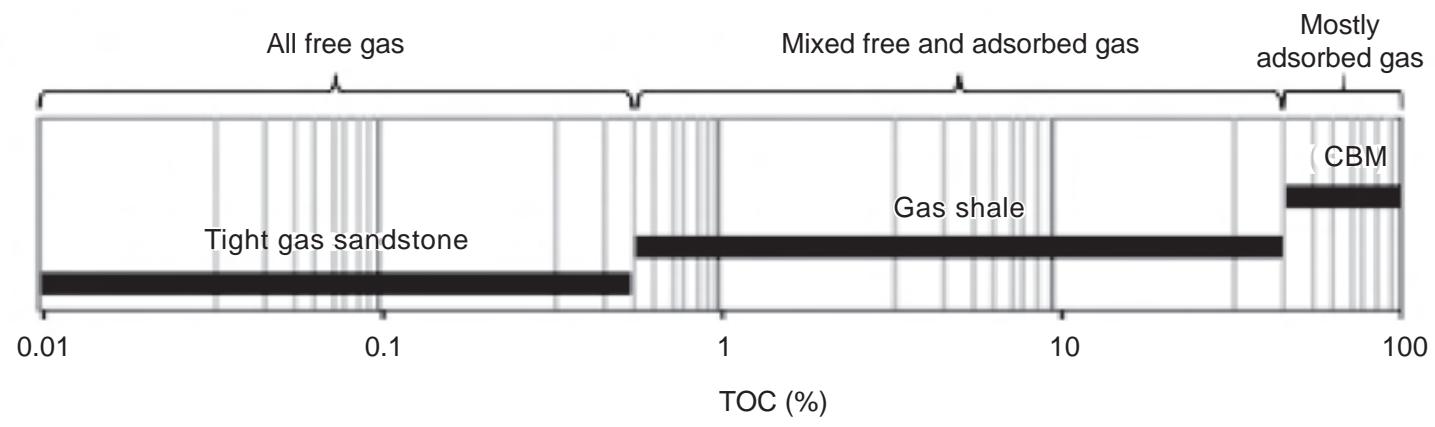

a)

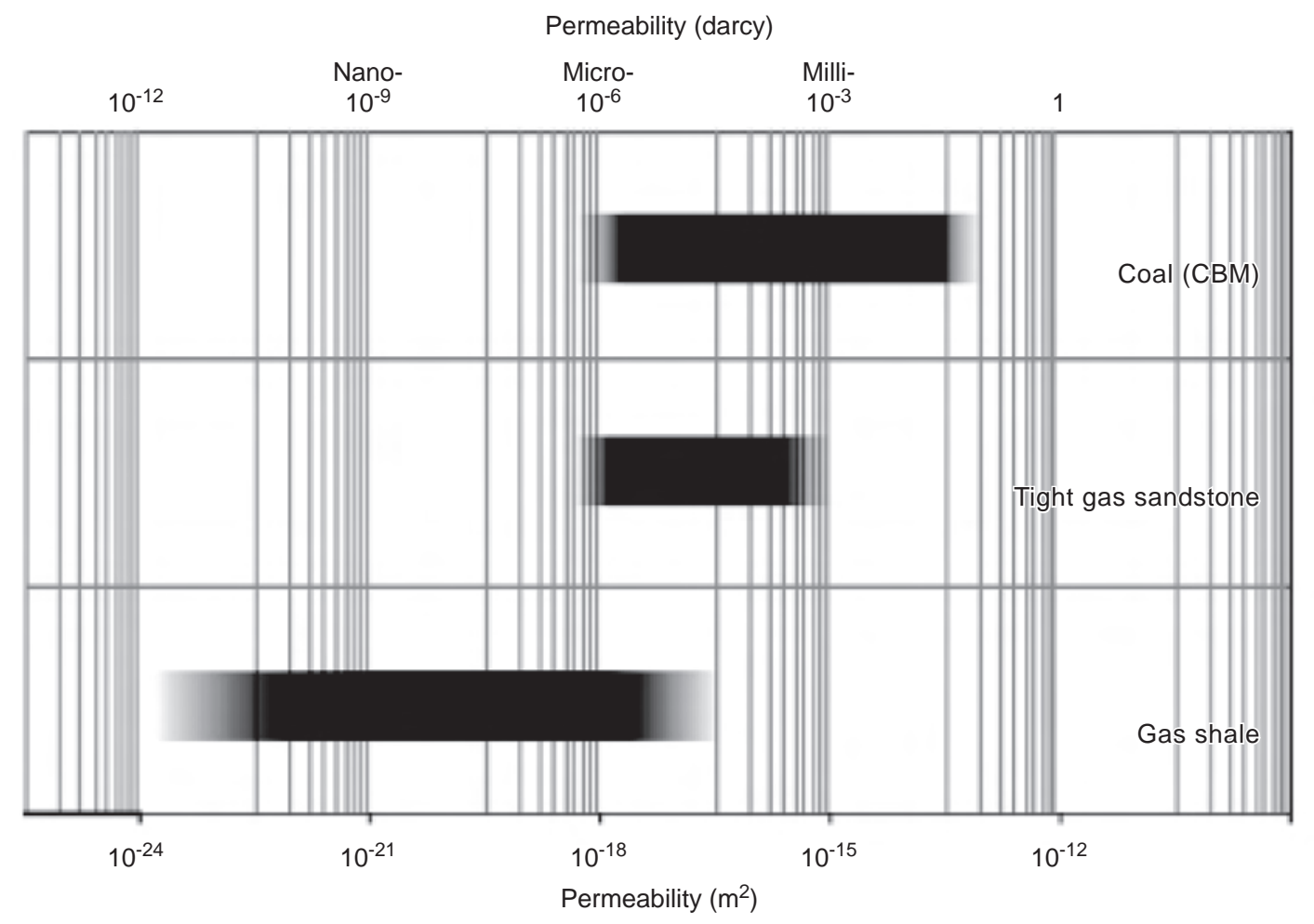

Figure 2

Typical TOC contents a) and permeability ranges b) of unconventional reservoir rocks for gas.

controlled by the long-term integrity and efficiency of surrounding seal formations. Hildenbrand et al. (2006) compiled and systematically evaluated available experimental sorption data to establish general relationships amenable to calculation schemes and basin modelling. A set of functions was proposed that provide a means to estimate the variation of sorptive gas storage capacity of coals with pressure, temperature and rank evolution during basin evolution. The application of these relationships to complex burial and uplift histories reveals the changes in sorption capacities of individual coal seams and may help to explain or interpret the present-day stage of gas saturation. In Figure 6, calculated sorption capacity $v s$ depth curves are shown for methane on coals assuming normal hydrostatic and geothermal gradients. The influence of water content on the sorption capacity is clearly seen from this set of curves.

During burial and uplift the sorption capacities of coal seams and gas shales vary systematically, mainly due to variations in pressure and temperature conditions, but also due to the evolution of the thermal maturity of the organic matter. In 


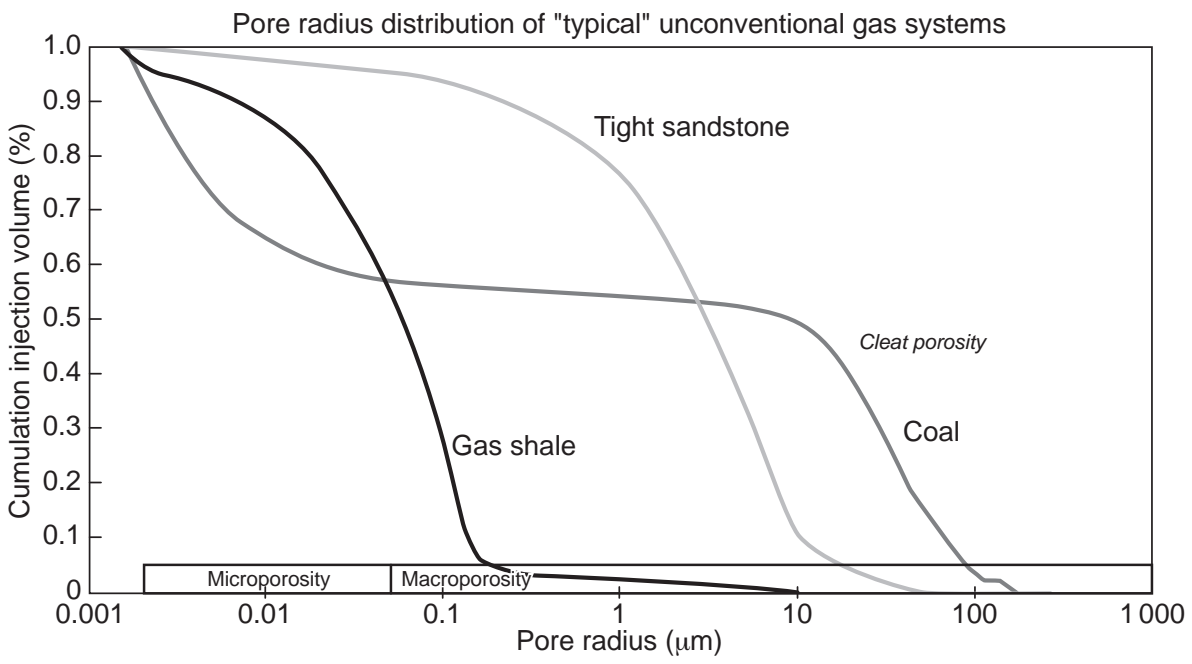

Figure 3

Typical pore size distributions of coals, gas shales and tight sandstones.

combination with gas generation and migration processes this may result in a complex scenario of under-saturation and gas leak-off due to over-saturation in different depth intervals. The integration of sorption and desorption processes with gas generation and migration is one of the imminent challenges in unconventional gas system analysis.

The term "Tight Gas Reservoir" lacks a formal definition. Law and Curtis (2002) defined low permeability sandstone reservoirs as those exhibiting permeability coefficients below $0.1 \mathrm{mD}$. The value of $0.1 \mathrm{mD}$ has been committed as a political margin in the USA to determine which wells receive governmental funding for gas production. Holditch (2006) defined them as "a reservoir that cannot be produced at economic flow rates nor recover economic volumes of natural gas unless the well is stimulated by a large hydraulic fracture treatment or produced by use of a horizontal wellbore or multilateral wellbores". Tight gas sandstones have usually very low TOC contents (Fig. 2) and have been charged with hydrocarbons from external sources. Pore radii are mainly in the micrometer range, although sub-micrometer pores are abundant as well (Fig. 3).

\section{REGIONAL GEOLOGY}

The structural and sedimentary evolution, salt tectonics, and fluid dynamics in the Central European Basin System have recently been summarized by Littke et al. (2008a). Basically, all stratigraphic units ranging from Pre-Devonian to Quaternary are present. Within the basin, Pre-Devonian rocks are largely unknown, because they are situated at great depth.

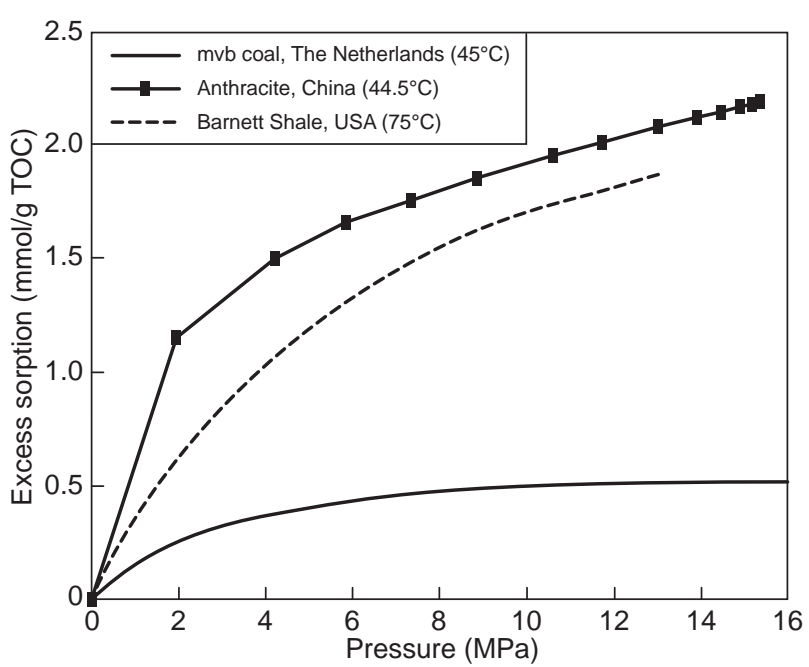

Figure 4

High-pressure excess sorption isotherms for methane on coals of different rank (mvb = medium volatile bituminous) and gas shale. Excess sorption values in $\mathrm{mmol} / \mathrm{g}$ TOC $(1 \mathrm{mmol} / \mathrm{g}$ $=24.5 \mathrm{Std} \mathrm{m}^{3} / \mathrm{t}$.

However, they occur at the southern, eastern and northern basin margin in outcrops or close to the surface. Clastic sedimentary rocks predominate and black shales are common such as the Cambrian Alum Shale in Scandinavia (Buchardt et al., 1997) and Silurian black shales in Poland and other eastern Baltic states (Zdanaviciutė and Lazauskiene, 2007).

Devonian and Lower Carboniferous sediments were deposited at a passive continental margin mainly in (shallow) marine environments (Oncken et al., 1999). They crop out in various mountain belts at the southern margin (e.g. Rhenish 


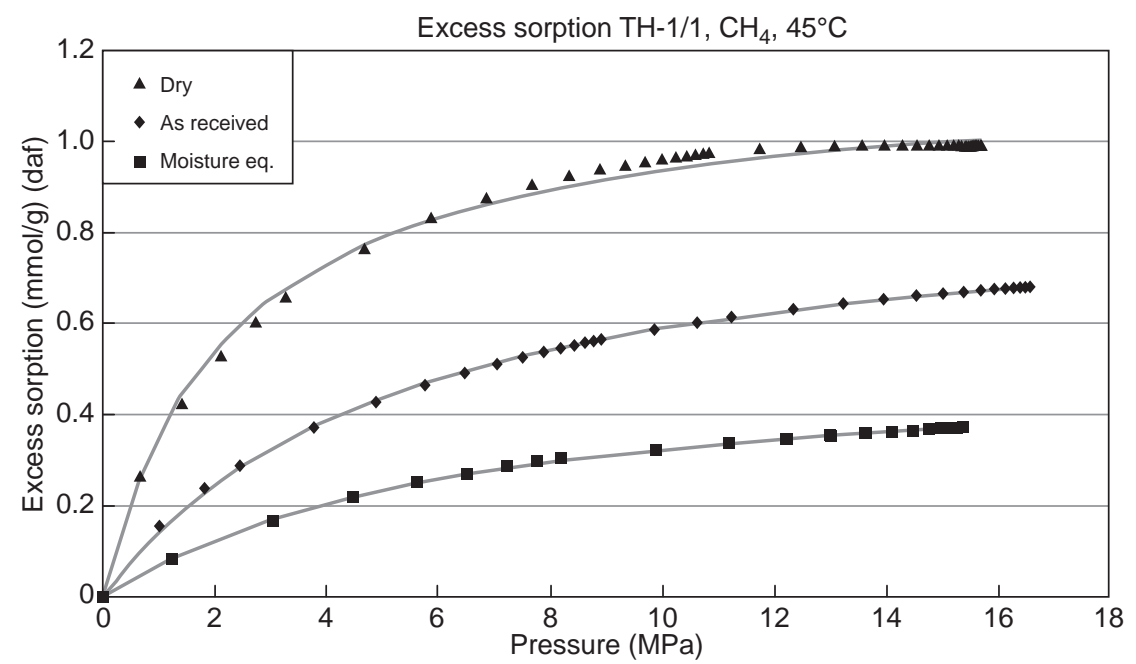

Figure 5

Effect of moisture content on high-pressure excess sorption isotherms for methane on coals. Excess sorption values in $\mathrm{mmol} / \mathrm{g}$ dry ash-free $\operatorname{coal}\left(1 \mathrm{mmol} / \mathrm{g}=24.5 \mathrm{Std} \mathrm{m}^{3} / \mathrm{t}\right)$.

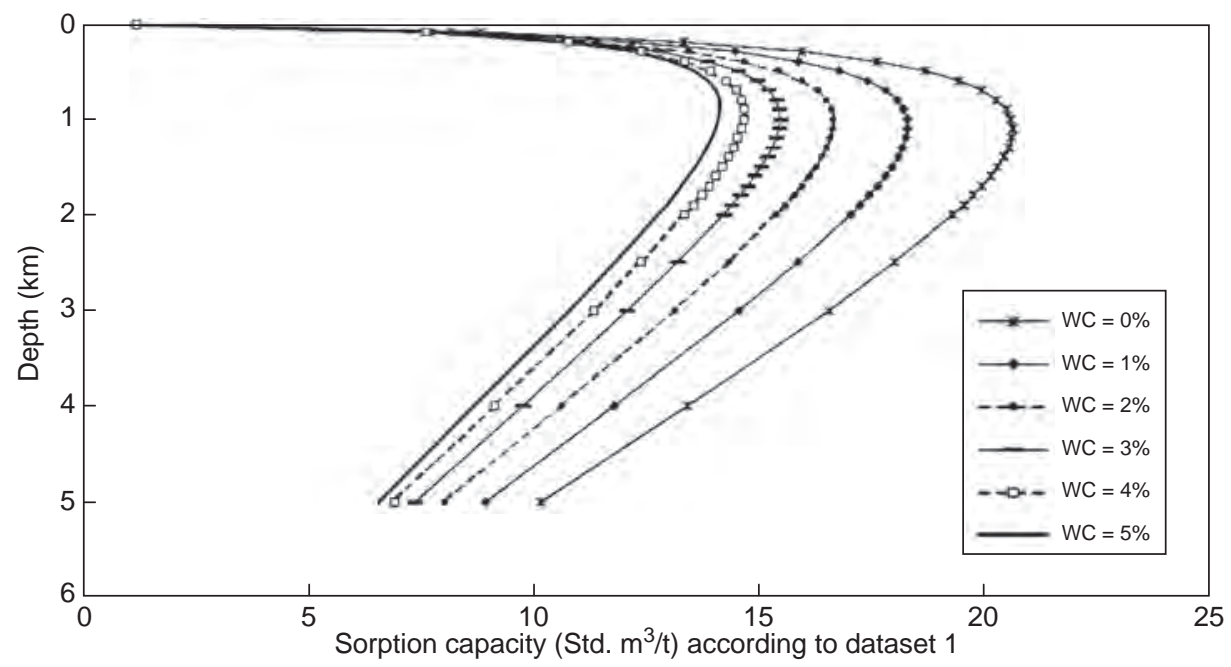

Figure 6

Evolution of methane sorption capacity of coal seams with depth (after Hildenbrand et al., 2006) documenting the influence of pressure (hydrostatic gradient), temperature (geothermal gradient of $3 \mathrm{~K} / 100 \mathrm{~m}$ ) and moisture content. Excess sorption values in mmol/g dry ash-free coal. $(1 \mathrm{mmol} / \mathrm{g}=24.5 \mathrm{Std} \mathrm{m} 3 / \mathrm{t})$.

Massif, Harz mountains) and have been drilled at few places within the basin. Towards the north, these units dip to considerable depth, the top Carboniferous reaching about 10 kilometres in the Hamburg area (Fig. 1). Here, the Paleozoic is overlain by thick Permian, Meso- and Cenozoic sedimentary successions (Stollhofen et al., 2008; Fig. 7). The Devonian is mainly composed of clastic rocks, but contains also thick reef-derived carbonates of late Mid-Devonian to early Late Devonian age. The Lower Carboniferous (Mississippian) consists of dark coloured carbonates in the north and west ("Kohlenkalk-facies"; Fig. 8) and of dark coloured shales further to the south and southeast ("Kulm-facies"; Ziegler, 1990; Kombrink, 2008). These marine facies are overlain by Upper Carboniferous (Pennsylvanian; Fig. 8) clastic sediments which are predominantly of terrestrial origin. In a paralic, tropical environment, widespread coastal peat swamps developed leading to a thick succession with abundant coal seams (Fig. 7, 8). These coal-bearing strata are the source for 


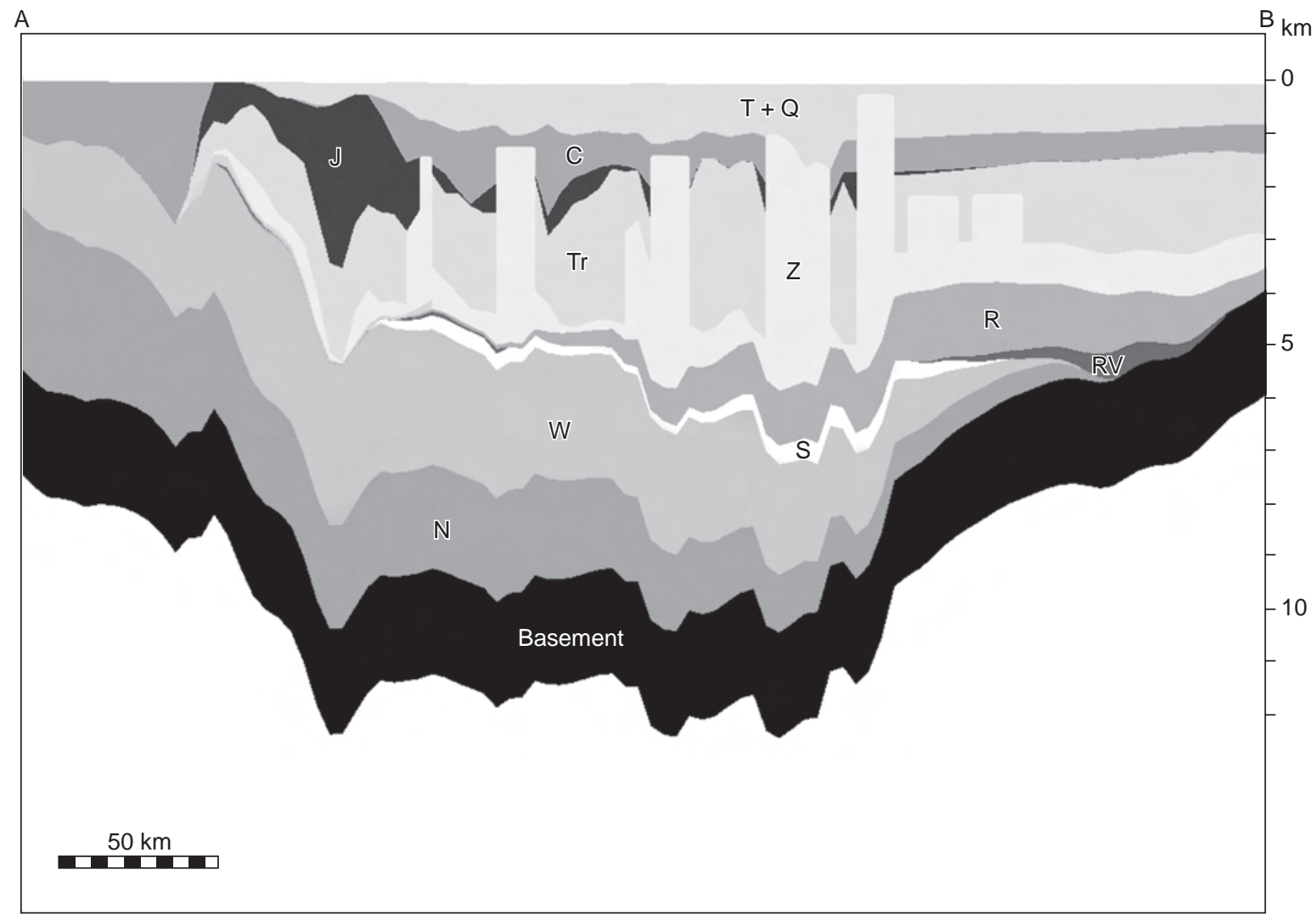

Figure 7

Schematic cross section through the basin (for location see Fig. 1) without structural details. Note that Carboniferous units are very thick and close to the surface in the south, where high potential for CBM and gas shale exploration is expected (Z: Zechstein, R: Rotliegend, RV: Rotliegend volcanics, S: Stephanian, W: Westphalian, N: Namurian (see Fig. 8).

most of the gas in conventional reservoirs in the basin (Lokhorst et al., 1998). When the continent moved northwards, first red-coloured sediments developed which contain only little organic matter (Fig. 8). Sedimentation and subsidence during the Namurian and Westphalian were greatly controlled by Variscian orogenesis (Oncken et al., 1999) leading to flexural subsidence north of the Variscian front. However, the basin geometry and subsidence cannot be explained by loading of the crust alone, especially for Namurian times (Kombrink et al., 2008); therefore Dinantian and potentially Namurian rifting is assumed. Variscian folding and faulting affected the southern part of the basin significantly, but is absent in the north.

During the Permian a major rifting event initiated the evolution of the Central European Basin system. In the following, volcanic sequences with a thickness of up to $2250 \mathrm{~m}$ (north of Berlin; Breitkreuz et al., 2008) developed which were followed by clastic sediments (Stollhofen et al., 2008) and first salt deposits. These often red coloured continental deposits ("Rotliegend"; see Fig. 8) were followed by thick marine evaporite sequences ("Zechstein") during the Late Permian. In the following, thick Triassic sediments were deposited, especially in the area of the Glückstadt Graben (see Fig. 7) and the Polish Basin (Fig. 1, 9). The Jurassic is usually thinner, but there are exceptions such as the Lower Saxony Basin (Fig. 1), where a thick Upper Jurassic/Early Cretaceous sequence developed (Adriasola Munoz et al., 2007; Fig. 7, 9). Cretaceous and Tertiary units reach great thickness in the area of the North Sea, but also in the Pompeckj Block (Fig. 9), whereas they are much thinner in other subbasins. Aside from the Variscian Unconformity which affected a large part of the area, Late Jurassic (Kimmerian) and early Late Cretaceous inversion events affected specific parts of the basin with significant eroded thickness. More information on the sedimentary and tectonic evolution is found in Littke et al. (2008a).

The basin is strongly affected by salt tectonics containing numerous salt walls, diapirs, and pillows. Some of these structures reach the surface and the total salt thickness can reach six-seven kilometers in the northern part of the basin. Salt 


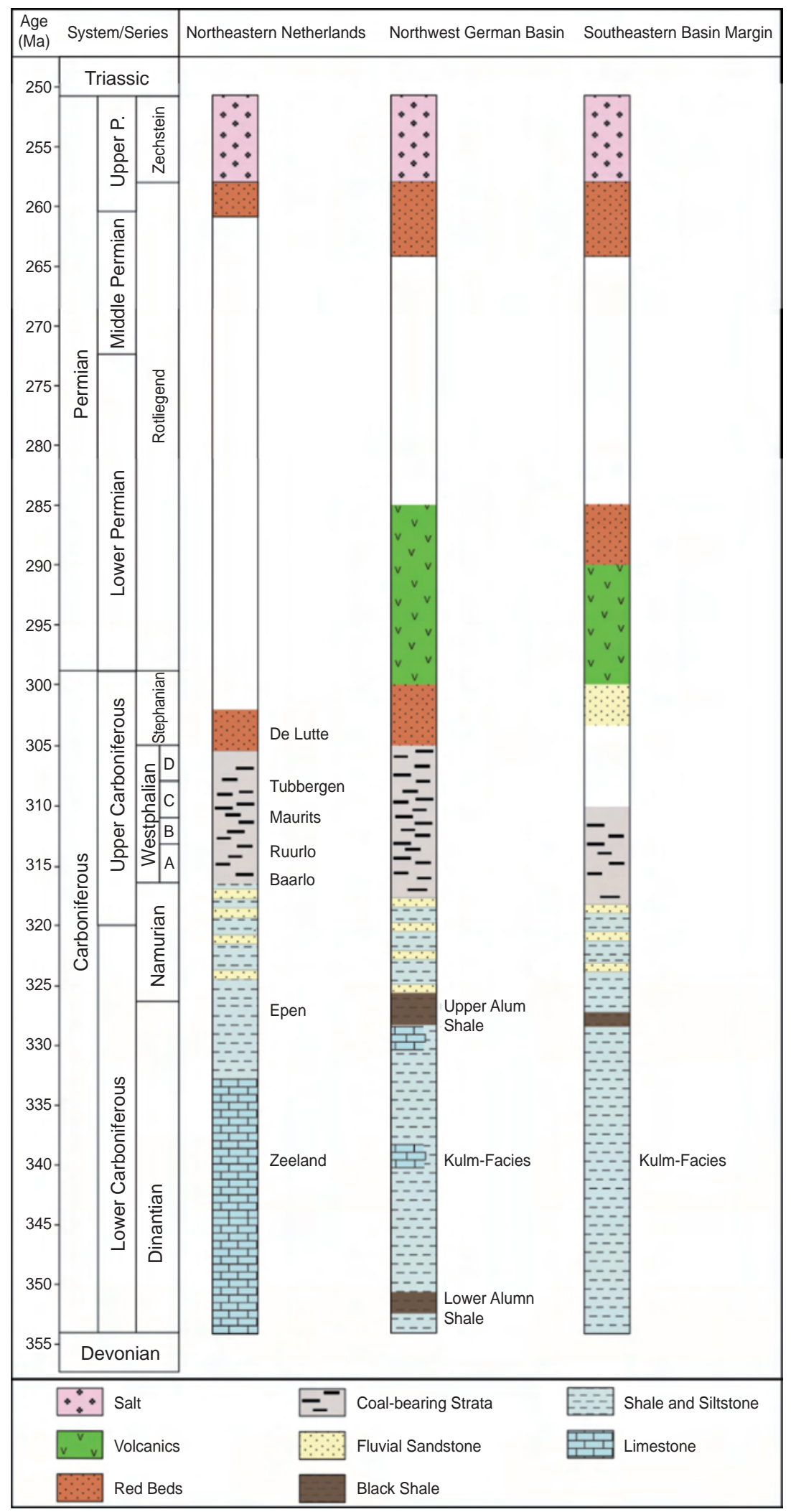

Figure 8

Stratigraphic columns for the Carboniferous and Permian in the Central European Basin, ordered from west (Netherlands, left column) to east (right column). Data after Kombrink (2008) and Ziegler (1990). 


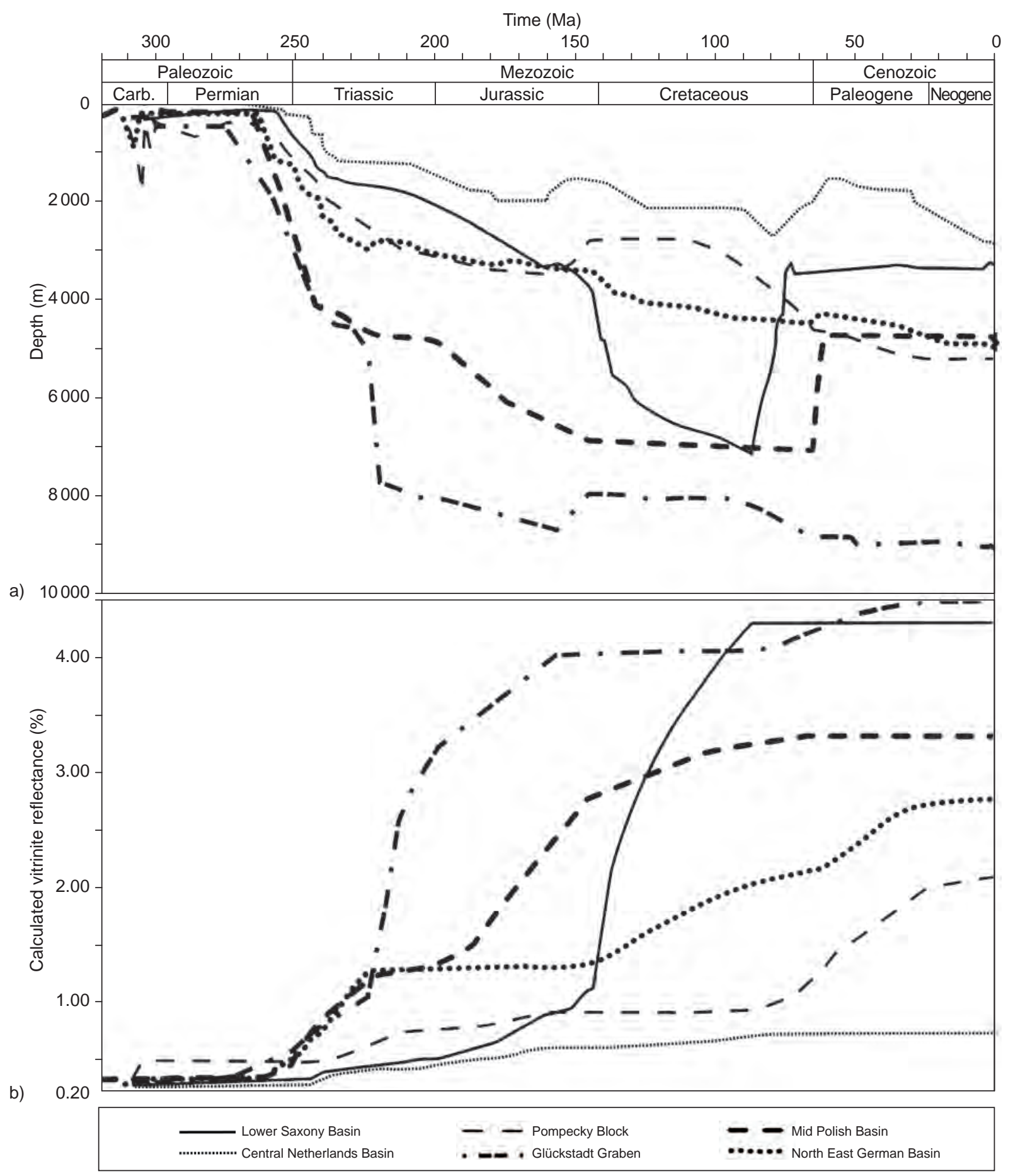

Figure 9

Burial trends a) and maturity-time curves b) for the top Carboniferous/base Permian in different subbasins (modified from Littke et al., 2008b).

acts as an important seal for petroleum accumulations. Gas accumulations are mainly sourced by Upper Carboniferous coal-bearing strata and mainly occur in Permian (Rotliegend sandstones and Zechstein carbonates) rocks, but also in the
Triassic and Carboniferous, whereas oil accumulations are mainly sourced by Toarcian "Posidonia Shale" and occur in Jurassic and Cretaceous rocks. In the east, oil accumulations are also related to Zechstein carbonates. 
It should be noted that present-day burial depth in the southern part of the Central European Basin system is not equivalent to maximum burial depth. Figure 9 shows typical burial history and maturation trends for different parts of the basin. Clearly, deposition of thick Triassic sequences in part of the basin led to early maturation and petroleum generation, whereas other areas (e.g. Pompeckj Block) reached maximum burial and highest temperatutes only during the Tertiary. This led to late gas generation from the Carboniferous coal-bearing source rocks. Uplift and erosion reached maximum values of 6 kilometres in the Lower Saxony Basin resulting in the occurrence of surface-near highly mature, gas-bearing sequences (Fig. 9). These comprise the gas-rich Pennsylvanian anthracite coals of the Ibbenbüren area as well as highly mature Liassic and Early Cretaceous marlstones and black shales (Toarcian Posidonia Shale and Wealden Shales; Berner et al., 2010).

\section{METHODS}

In order to understand the large-scale geological evolution of the study area, a 3D has been built using PetroMod software of Schlumberger IES, Germany. Several maps from this model are presented here. Details on the input and calibration of this model have recently been published in Uffmann et al. (2010), based on a 3D structural model of Maystrenko et al. (2010). The thermal model is mainly based on a Permian rifting event affecting the entire area. The Mesozoic thermal history is different in the various subbasins, taking e.g. a small scale Late Jurassic rifting event in the Lower Saxony Basin (Fig. 1) and Tertiary volcanic activity in the Northeast into account (Uffmann et al., 2010).

\section{TIGHT GAS SANDSTONES}

Research and exploration for tight gas reservoirs has been regionally focused on North America, where considerable experience has been gathered. Haines (2005) provides an overview on known and producing tight gas plays in the USA and Canada. Tight gas sandstones exist also in the Central European Basin system in northern Germany and the Netherlands, where numerous conventional reservoirs are known (Fig. 1). These reservoirs contain variable, often high, percentages of nitrogen gas, carbon dioxide, and hydrogen sulphide (Krooss et al., 2008). Due to deep burial and a complex cementation history, many gas-bearing sandstones in the Carboniferous and Permian (Rotliegend) have low permeabilities. Hydrocarbon gases are characterized by high $\delta^{13} \mathrm{C}$ values and low methane over ethane and propane ratios (Fig. 10; Lokhorst et al., 1998) clearly indicating that the gas is of thermal origin. The principal source rocks are Pennsylvanian (Upper Carboniferous) coal-bearing strata of great cumulative thickness that have reached a maturity stage sufficient for gas generation (Lutz et al., 1975; Drozdzewski et al., 2009). Additional source rocks (black shales) are present in the Mississippian (Lower Carboniferous) and potentially in the Devonian.

Both, conventional and unconventional sandstone reservoirs occur in the Permian and Carboniferous as well as in the Triassic (Buntsandstein) and basically in the same region (Fig. 1). Especially the Permian Rotliegend is presently a key exploration target. In general, the sedimentary Rotliegend formation exhibits a high degree of heterogeneity in terms of facies. An example is shown in Figure 11. Best reservoir qualities exist in dry dune facies (Fig. 12), where both permeabilities and porosities are high (Gaupp et al., 2005; Pusch et al., 2005). In the tight gas sandstones, porosities (5-15\%) and reservoir thicknesses $(40-100 \mathrm{~m})$ are satisfactory providing a good storage potential. However, permeabilities are low, varying between less than $10 \mu \mathrm{D}\left(10^{-17} \mathrm{~m}^{2}\right)$ and $1 \mathrm{mD}$ $\left(10^{-15} \mathrm{~m}^{2}\right)$.

Investigations by Gaupp and co-workers (e.g. Gaupp et al., 2005; Schöner and Gaupp, 2005) revealed that porosity in these reservoirs is not linearly related to permeability, which is mainly due to differences in facies and burial history (Schwarzer and Littke, 2007). Burial history also controlled the impregnation of the reservoirs with oil, which is now present as solid bitumen in many sequences. The substantial permeability reduction is mainly due to clay mineral overgrowth on the primary quartz grains of the sandstones (Fig. 12b) which in turn depends on burial history, but also on the proximity of Rotliegend reservoirs to faults (Gaupp et al., 2005). Especially the presence of a meshwork of illite (IM in

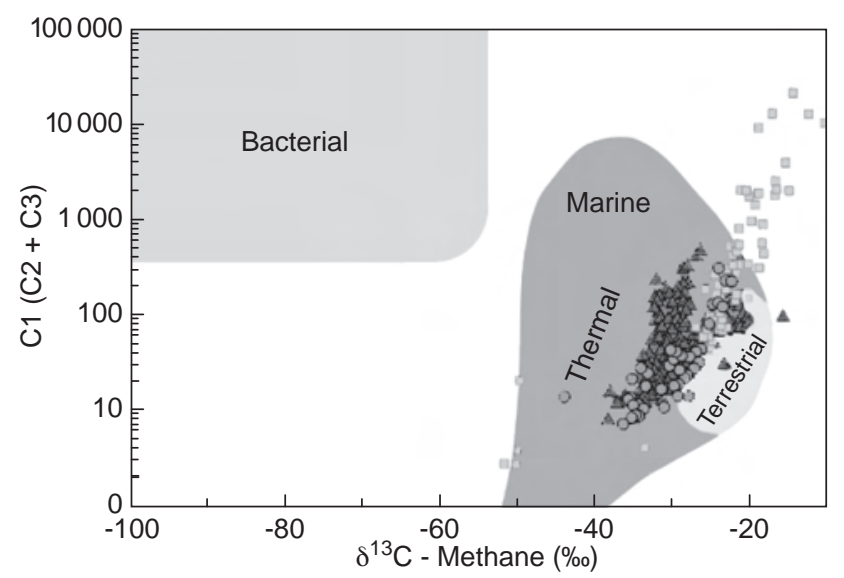

Figure 10

Composition of natural gases in Palaezoic reservoirs of the Central European Basin system (from Gaupp et al., 2008 after Lokhorst et al., 1998). Data are classified by formations: Carboniferous (circles), Rotliegend (triangles) and Zechstein (squares), but not for regional distribution within the basin. 


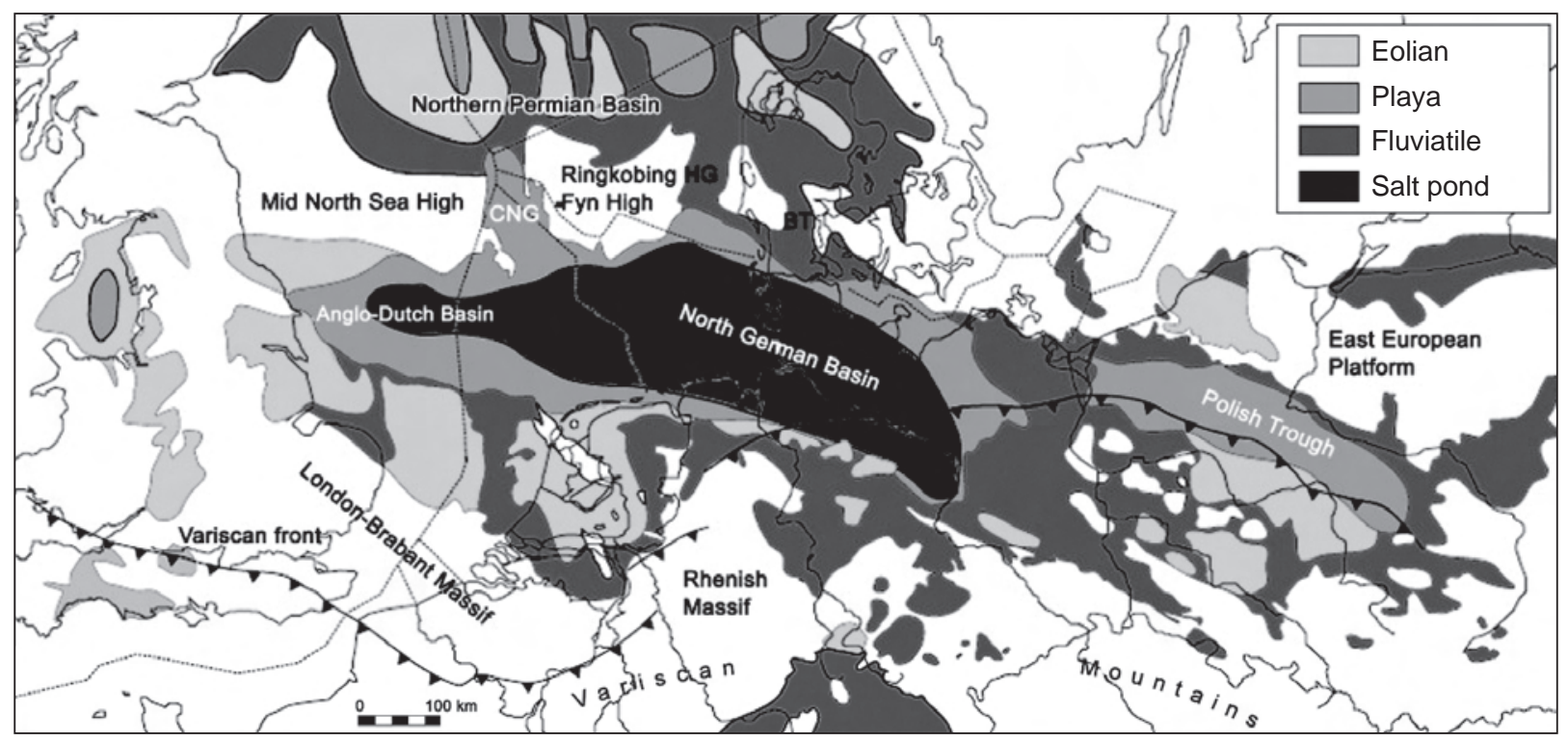

Figure 11

Present-day distribution and facies map of the Upper Rotliegend Group (late Middle to early Late Permian) in the Southern Permian Basin (Geluk, 2005). BT: Bramble Trough; CNG: Central North Sea Graben; HG: Horn Graben.

Fig. 12b) greatly diminishes permeability and imposes a strong influence on flow properties of gas and water. Interestingly, these damaging cements occur often in areas of initially high permeabilities, i.e. in the dry dune facies. On the other hand, areas with only low amounts of the dry dune facies are often characterized by a lack of damaging cements and have favourable permeabilities leading to a reservoir quality inversion (Pusch et al., 2005). Cementation by hematite or tangential chlorite has less influence on permeability than cementation by radial and subparallel illite.

One important example of a tight gas field is situated in northwestern Germany close to the Dutch border, at about $4400 \mathrm{~m}$ depth and covers an area of $4.7 \mathrm{~km}^{2}$ dipping 4.5 ${ }^{\circ} \mathrm{ENE}$ (Koehler, 2006; Fig. 13). Reservoir thickness reaches almost $80 \mathrm{~m}$ and temperature is at $150^{\circ} \mathrm{C}$. Up until now six wells have been drilled. This Permian reservoir belongs to the Elbe Subgroup and contains mainly desert plain sediments, dominated by aeolian dunes. Five drying upward cycles are visible in the reservoir (Koehler, 2006). Pennsylvanian coal-bearing strata provide the source rock. The average porosity is $9.7 \%$ and water saturation amounts to $34 \%$. Permeability values range between 0.02 and $0.15 \mathrm{mD}$. Due to lateral facies boundaries differences between vertical and horizontal permeability can reach ratios of 1:10 (Koehler 2006). This type of a low permeable reservoir requires special treatment during development and production which can be challenging. Horizontal drilling and vertical, multiple hydro fracing is applied to stimulate the gas flow. Stabilization of the fractures is attained by injecting proppant-containing fluid into the formation above fracture pressure. Fracing enhances production but also bears the risk of mobilizing fines. These can clog up pore throats during re-sedimentation and reverse the intended effect (Liermann and Jentsch, 2003). Petrophysical and geomechanical characterization of tight gas reservoir rock types before fracing is a key to quantify risks.

\section{GAS SHALES}

Paleozoic gas shales are present in the Upper Permian, Mississippian and Pennsylvanian, Middle and Upper Devonian, and pre-Devonian of the Central European Basin system. Except for Pennsylvanian strata these shales were deposited under persistently marine conditions and in part are organic-rich. Virtually all these rocks have reached the gas generation stage and some of them have reached a level of maturation close to the greenschist facies. This is clearly the case in the southern Rhenish Massif and Harz (Fig. 1), where many outcrops are available. Bituminous impregnations in Upper Devonian reef carbonates clearly point to the existence of a former petroleum system with Middle Devonian source rocks ("Wissenbacher Schiefer"; Krebs, 1978). In the Central European Basin itself, these rocks are usually at depths greater than 5 kilometres (with few exceptions, especially in 

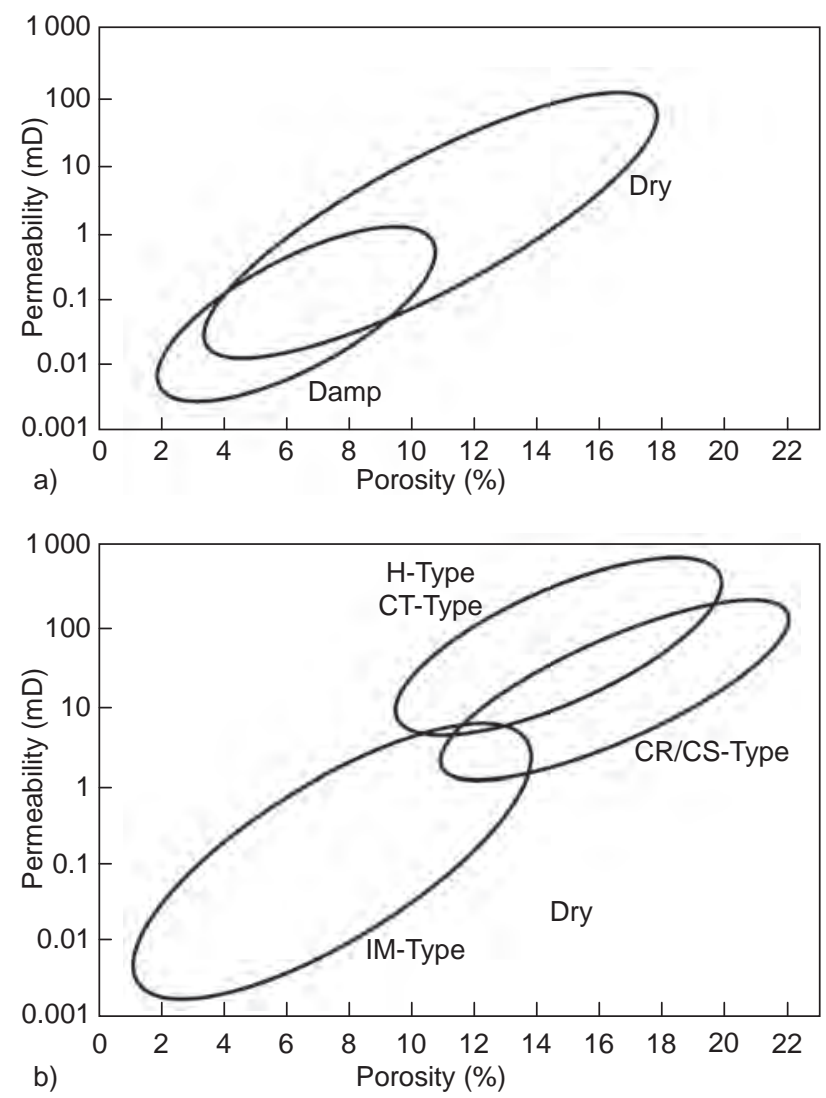

Figure 12

Correlation of porosity (\%) and permeability (mDarcy) of the facies types Dry Aeolian and Damp Aeolian based on 583 datasets from wells a) and for sandstones with important diagenetic types b); IM is flakey illite, $\mathrm{CR} / \mathrm{CS}$ is radial chlorite/subparallel chlorite, $\mathrm{H} / \mathrm{CT}$ is tangential chlorite/ hematite (modified after Gaupp et al., 2005).

the uplifted area close to Ibbenbüren, in the Harz mountains southeast of Hannover, and in northeasternmost Germany; see Fig. 1). Therefore, they have only been penetrated by very few deep wells and insufficient knowledge on their gas potential exists. It should be noted that the Mesozoic shales (like the above mentioned Lower Jurassic Posidonia Shale) have reached the gas-generation stage in the uplifted areas of the basin, where especially the Wealden attains great thickness; these Mesozoic shales certainly possess a shale gas potential there (Williams, 2009). In other areas of the basin, the Mesozoic sequence is too immature and has not reached the gas generation stage.

A prominent example of a potential shale gas system occurs at relatively shallow depth along the northern margin of Central Europe (southern Denmark to southern Sweden). The Scandinavian Alum Shale (Upper Cambrian to Lower Ordovician) was deposited in shallow marine water and is characterised by a significant potential for generating and storing gas at all maturity levels, thanks to its unusual organic matter structure (Horsfield et al., 1992). The Total Organic Carbon (TOC) content can exceed 20\% (Schovsbo, 2003; Nielsen and Schovsbo, 2007, and references therein), and a significant gas potential has also been found by hydrous pyrolysis experiments (Buchardt, 1999). Lithofacies of the Alum Shale controls gas generation and today's gas content. However, lithofacies is highly variable except for the Skåne region (southern Sweden) where black mudstones with bituminous limestone concretions predominate (Thickpenny, 1984), and where thickness can be as high as $100 \mathrm{~m}$ (Fig. 14; Buchardt et al., 1997). Deposition in shallow water covering a gentle sea-floor topography was coupled to restricted detrital supply. As a consequence illite is the dominant silicate mineral of black laminated mudstones and quartz contents are $25 \mathrm{vol} \%$ on average (borehole in the Billingen area, southern Sweden; Armands, 1972). In other areas chlorite contents can exceed 50 vol\% (Snäll, 1988). This mineralogy is an important factor when planning hydrofracturing as it defines brittleness. In southern Sweden and northern Denmark, the Alum Shale displays organic matter content and type, maturity and thicknesses that are typical of productive shale gas areas (Dyni, 2006). Shallower Silurian shales may also be targeted due to high TOC contents (Schovsbo, 2002). Due to progressively deeper burial in the Danish sector the Alum Shale exhibits maturities of more than 2.7\% $\mathrm{VR}_{\mathrm{r}}$ (random vitrinite reflectance; Fig. 14) in the southern Baltic Sea region (Buchardt et al., 1997). At the northeastern margin of the Central European Basin (northeastern Germany) the Alum Shale can be detected as conductor by magnetotellurics, but is deeply buried. However, the shaly succession is regarded as a source rock with high gas potential (Hoffmann et al., 2001).

Marine, organic-rich sediments of the Silurian are widespread in Europe and contain intervals with TOC contents of more than 20\%. In Poland, the main target is the lower section of the Silurian shales that were deposited along the western slope of the East European Craton. Three prospective areas have been delineated within the Silurian of the East European Craton: the Baltic Basin, the Podlasie Depression and the Lublin Basin (Hadro, 2009). In the Danish-Polish Trough organic-rich sediments can be more than $200 \mathrm{~m}$ thick and are proven source rocks for oils in the Baltic region. In general, depth and maturity of the sedimentary organic matter increase from the northeastern part of the Baltic Syneclise towards the Teisseyre-Tornquist Zone (Lazauskiene et al., 2003; Zdanaviciute and Lazauskiene, 2004, 2007). These features reflect the development of the Baltic Basin as a passive-margin basin during the latest Precambrian to Middle Ordovician (Poprawa et al., 1999). The change from a passive to convergent margin setting is recorded by the gradually increasing subsidence which took place during the Late Ordovician-Early Silurian towards the southwest of the basin 


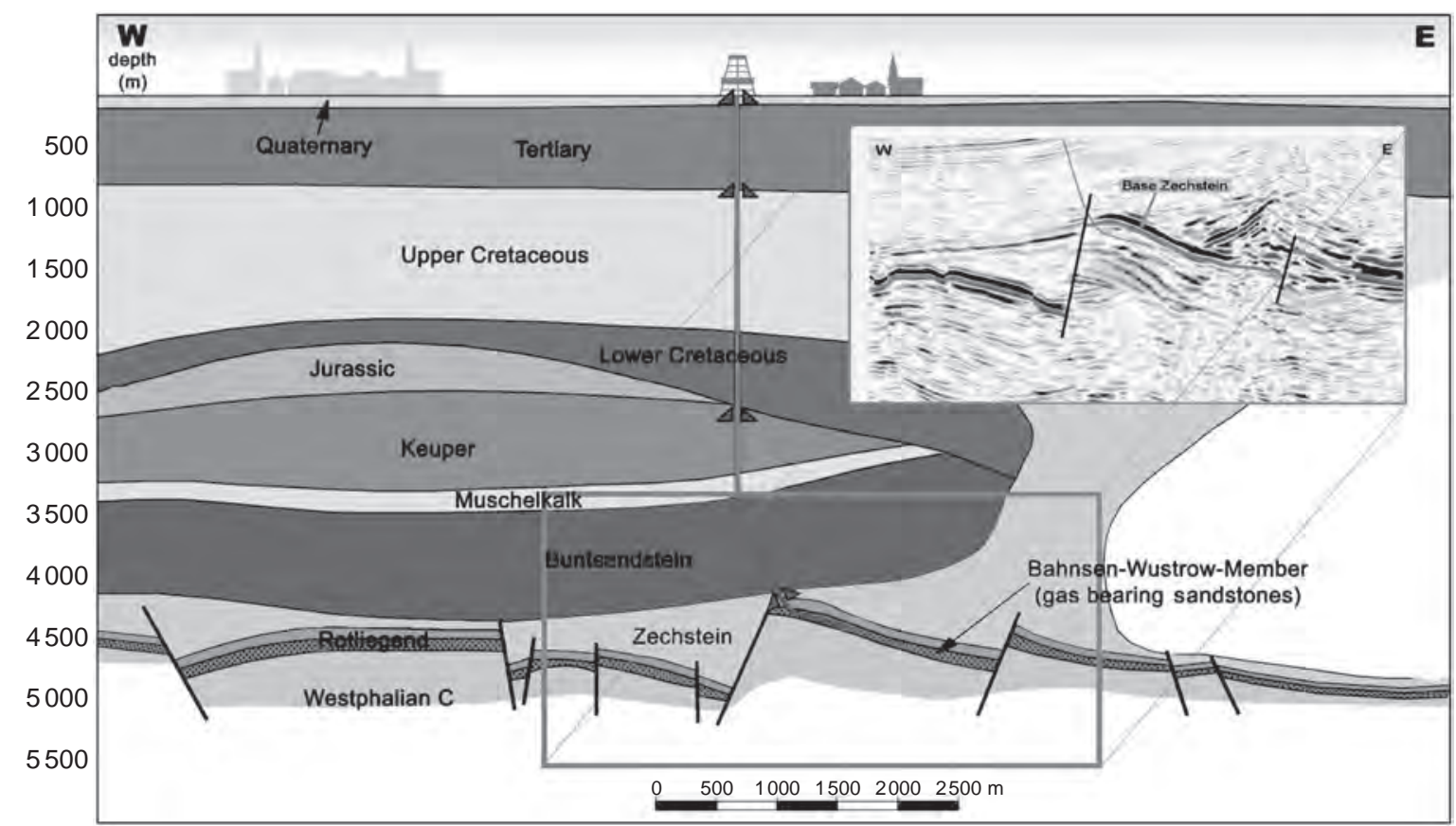

Figure 13

Schematic cross section through a tight gas reservoir in northern Germany (modified after Koehler, 2006).

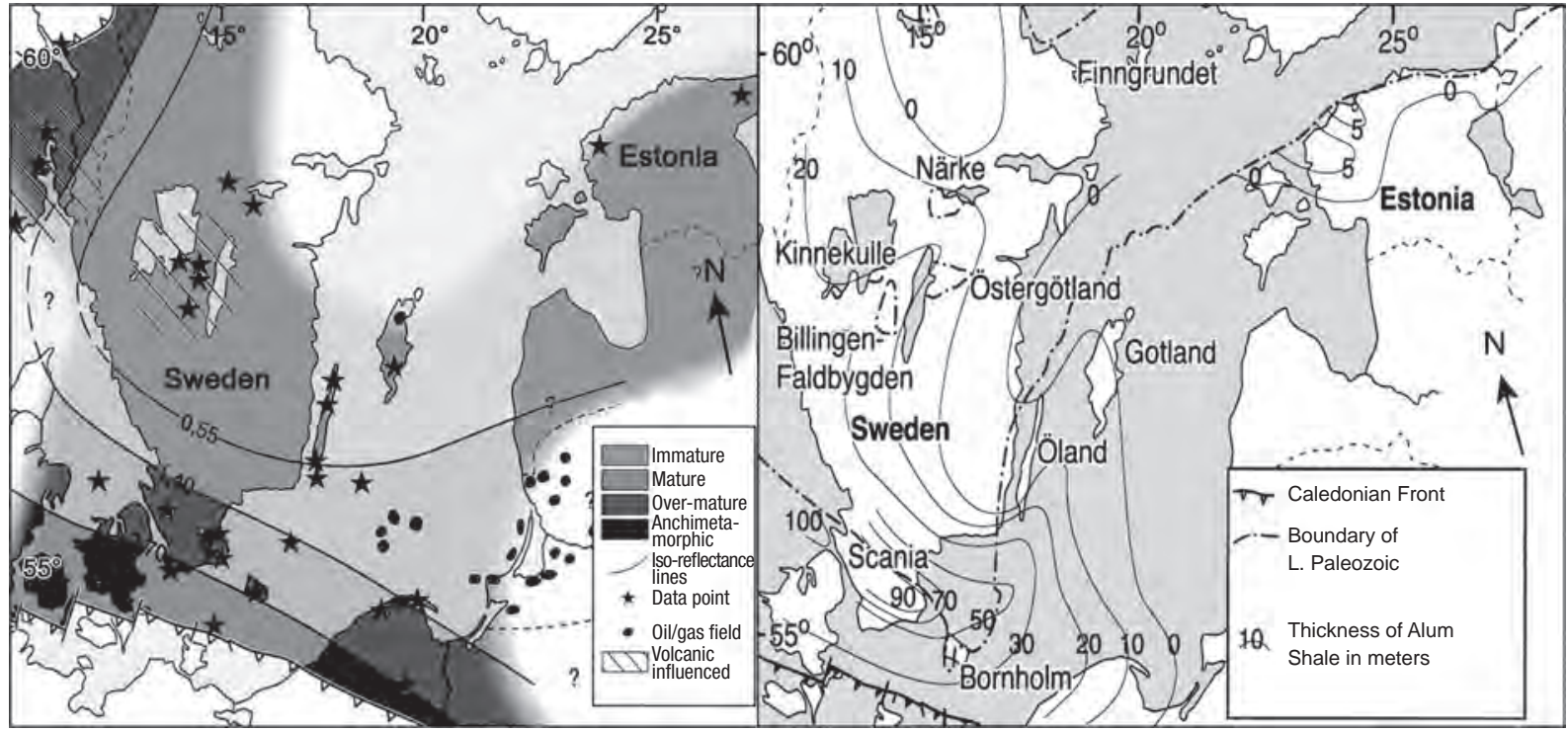

Figure 14

Thickness and maturity distribution of the Cambro-Ordovician Alum Shale (modified after Buchardt et al., 1997).

(Lazauskiene et al., 2003). While it is not clear yet whether its black shales of Llandovery age represent economically viable shale gas systems, Poland is certainly the focus of the most intense exploration activities for shale gas in Europe at the time of writing (Durham, 2010) and first wells have been drilled by now.

In the course of the Devonian and Carboniferous, the sedimentary facies changed from fully marine to fluvio-deltaic. 
During the Devonian, the "Old Red" continent existed in the north and northwest (e.g. in the area of Great Britain), whereas continental shelf deposition occurred further to the south and east (Ziegler, 1990). This Devonian sequence is at very great depth in most parts of the basin and has not been drilled except for few examples in northeastern Germany. At the southern and northern rims of the basin the Devonian occurs at shallow depth or crops out in mountain areas (e.g. the Rhenish Massif or Harz mountains). During the Middle Devonian black shales like the Wissenbacher Schiefer (today $0.2 \mathrm{wt} \%$ TOC and $\mathrm{VR}_{\mathrm{r}}>3 \%$ in the Harz mountains; Jordan and Koch, 1979) have been deposited in the areas of Germany and Poland. In the Late Devonian, shales are more abundant than in the Middle Devonian, but most of them are coloured red and green and contain little organic matter. However, clayey-marly sediments of Late Devonian age in Northeastern Germany are characterized by TOC contents ranging between $<0.2 \mathrm{wt} \%$ and $1 \mathrm{wt} \%$ (Schretzenmayr, 2004), but are too low on average according to classical gas shale considerations (cf. Curtis, 2002). An exception are the Kellwasser horizons across the Frasnian/ Famennian boundary which are known from outcrops in the southern part of the study area (e.g. Rhenish Massif, Harz mountains) containing partly high amounts of organic carbon (Schindler, 1992). Whereas these widespread Upper Devonian black shales are known petroleum source rocks in other parts of the European/northern African realm (e.g. Yahi et al., 2001), they are too thin and too mature for any gas shale exploration in the western part of the Central European Basin system (e.g. in: Bond et al., 2004; Riquier et al., 2006; Gerling et al., 1999a). The highest potential probably exists in the area of Poland, where these marly rocks reach thicknesses of more than $50 \mathrm{~m}$ with average TOC contents of about 2-3\% (Joachimski et al., 2001). It should be noted that these latter TOC values were measured on immature/early mature shales.

During the Mississippian, dark basinal marine shales were deposited ("Kulm" facies; Ziegler et al., 1990; Fig. 8, 15). In the south, up to $900 \mathrm{~m}$ thick, coarse-grained clastics with intercalated mudstones witness turbidite/mass flow sedimentation. Much of this clastic material was now derived from the south, i.e. the Mid-German Crystalline Rise rather than from the Old Red continent in the north (Ricken et al., 2000). In the northern Rhenish Massif the shaly Kulm facies has a thickness of 50 to $150 \mathrm{~m}$; in the deep well Münsterland 1,69 $\mathrm{m}$ of Lower Carboniferous sediments were encountered mainly as dark shales. Few data on organic carbon content exist. In the area of Wuppertal (Fig. 1) these rocks have gained a high thermal maturity (gas-prone) and contain TOC of more than $5 \%$ in some intervals, but of $1-2 \%$ on average; they have already lost part of the original organic matter and original TOC values were about twice as high as the present ones. It is important to note that "Liegende Alaunschiefer" (Rhenohercynian Alum Shale acc. Hoffmann et al., 2001) occur in the Kulm facies, and can be as thick as 20 metres along the northern margin of the Rhenish Massif (with TOC contents as high as $10 \mathrm{wt} \%$; Siegmund et al., 2002). However, the "Liegende Alaunschiefer" facies is only $7 \mathrm{~m}$ thick in well Münsterland 1 (Richwien et al., 1963).

During the Mississippian/Pennsylvanian transition the facies shifted from marine in the Namurian A to fluvio-deltaic (paralic) in the Late Namurian (Namurian C) and Westphalian. The lower part of the Namurian was essentially deposited in the same basin as the Lower Carboniferous (Dinantian). In the south a starved basin existed and contains interlayered greywackes/sandstones and shales (Fig. 15). The shales are usually dark grey to black and contain abundant organic matter. During the Namurian A, the Namurian "Hangender Alaunschiefer" (a younger Rhenohercynian Alum Shale; upper Alum Shale in Fig. 8) was deposited, and the basin was slowly filled by flysch sediments from the south and south-west. The distal flysch deposits of Namurian A to B age contain dispersed kerogen type III organic material (TOC contents between $<0.5$ to $>1 \%$; Gerling et al., 1999a). Basinal shaly sediments of early Namurian age can have TOC contents between $0.2 \mathrm{wt} \%$ and $8 \mathrm{wt} \%$ (well Schwalmtal 1, well Münsterland 1). Maturities of Namurian A sediments differ strongly between 3.3\% $\mathrm{VR}_{\mathrm{r}}$ (well Brakel 1; Teichmüller et al., 1979), through 3.5\% VR $\mathrm{V}_{\mathrm{r}}$ (well Schwalmtal 1; Krooss et al., 2005) and 4.6\% $\mathrm{VR}_{\mathrm{r}}$ (well Pröttlin; Mingram et al., 2005), to 5-6\% VR $\mathrm{VR}_{\mathrm{r}}$ (well Münsterland 1; Teichmüller et al., 1979). In terms of shale gas prospectivity, Namurian A sediments are too mature across large areas. Promising maturities of basal, TOC-rich (2-7\% TOC) Namurian may occur in the southwest of the Netherlands along the London Brabant Massif. In this area the Geverik member with a thermal maturity higher than $1 \% \mathrm{VRr}$ occurs at a depth of $900 \mathrm{~m}$ to $>5000 \mathrm{~m}$ with a thickness of 60-80 m (Muntendam-Bos et al., 2009).

However, no significant gas kicks have been reported from drilling shale intervals of Namurian age, and methane content of the drilling mud is $<0.5 \mathrm{vol} \%$ in well Münsterland 1 (Gedenk, 1964). None of these individual Namurian shales is very thick, but the total thickness of the shale/siltstone intervals is in the order of several hundred metres. Higher plant fossils are very abundant, and indeed much of the dispersed organic matter seems likely to be derived from higher land plants. In well Münsterland, the marine Lower Namurian sequence (Namurian A and B) has a total thickness of $1760 \mathrm{~m}$ of which about one third consist of dark mudstones/shales. Neither sandstones nor shales in the Pennsylvanian are laterally continuous; instead rapid facies changes are typical. In the area of the Netherlands and the United Kingdom, the analogue of the "Hangende Alaunschiefer" occurs as a shaly, bituminous facies of early Namurian age (Geverik member acc. van Buggenum and den Hartog Jager, 2007; Bowland Shale Formation acc. Hoffmann et al., 2001), whereas a shallowmarine-deltaic facies occupies the area northwest of the Danish-German border (Yoredale facies; Cameron, 1993). 

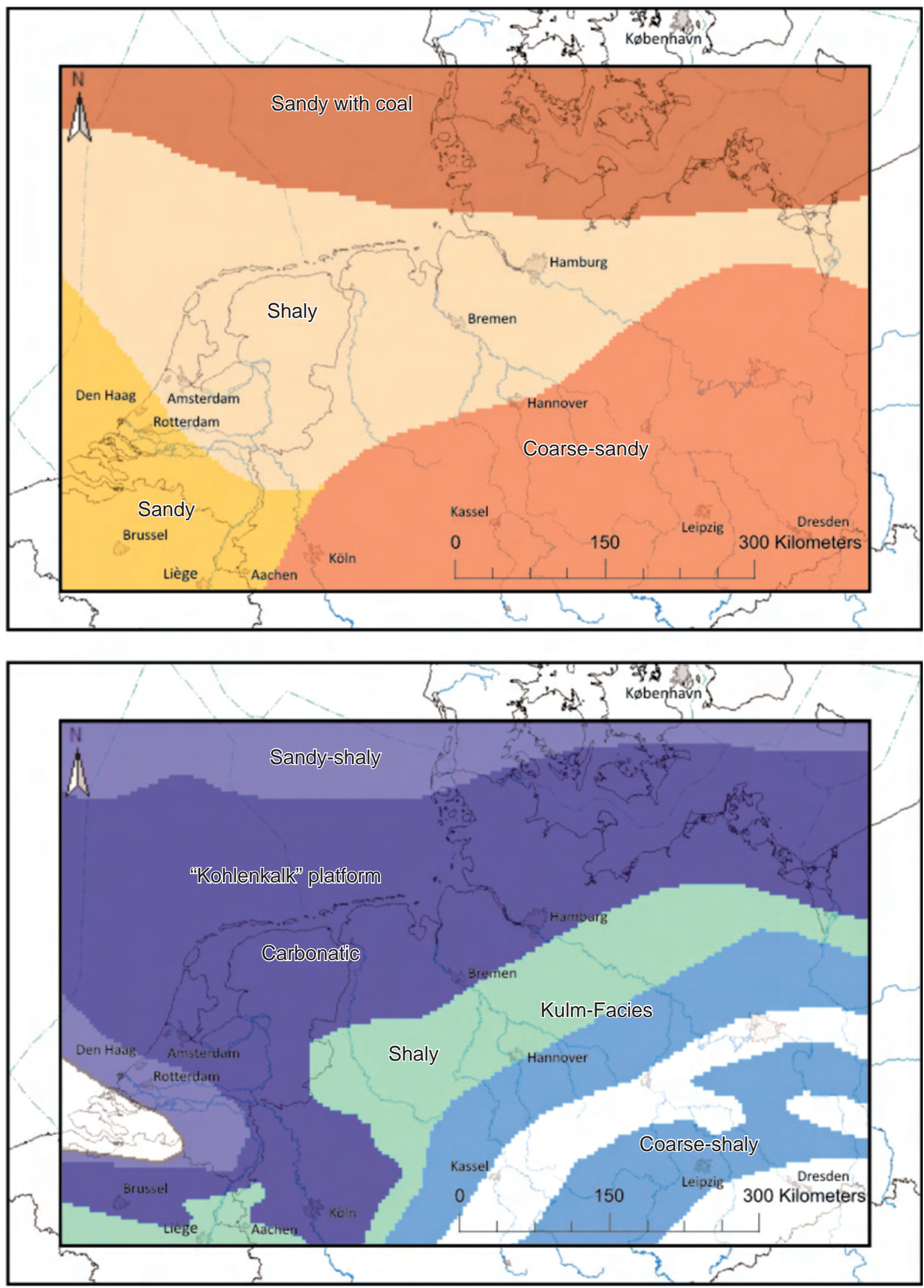

Figure 15

Sedimentary facies of Namurian (top) and Lower Carboniferous (bottom) rocks at the base of the North German Basin (modified after Ziegler, 1990). 


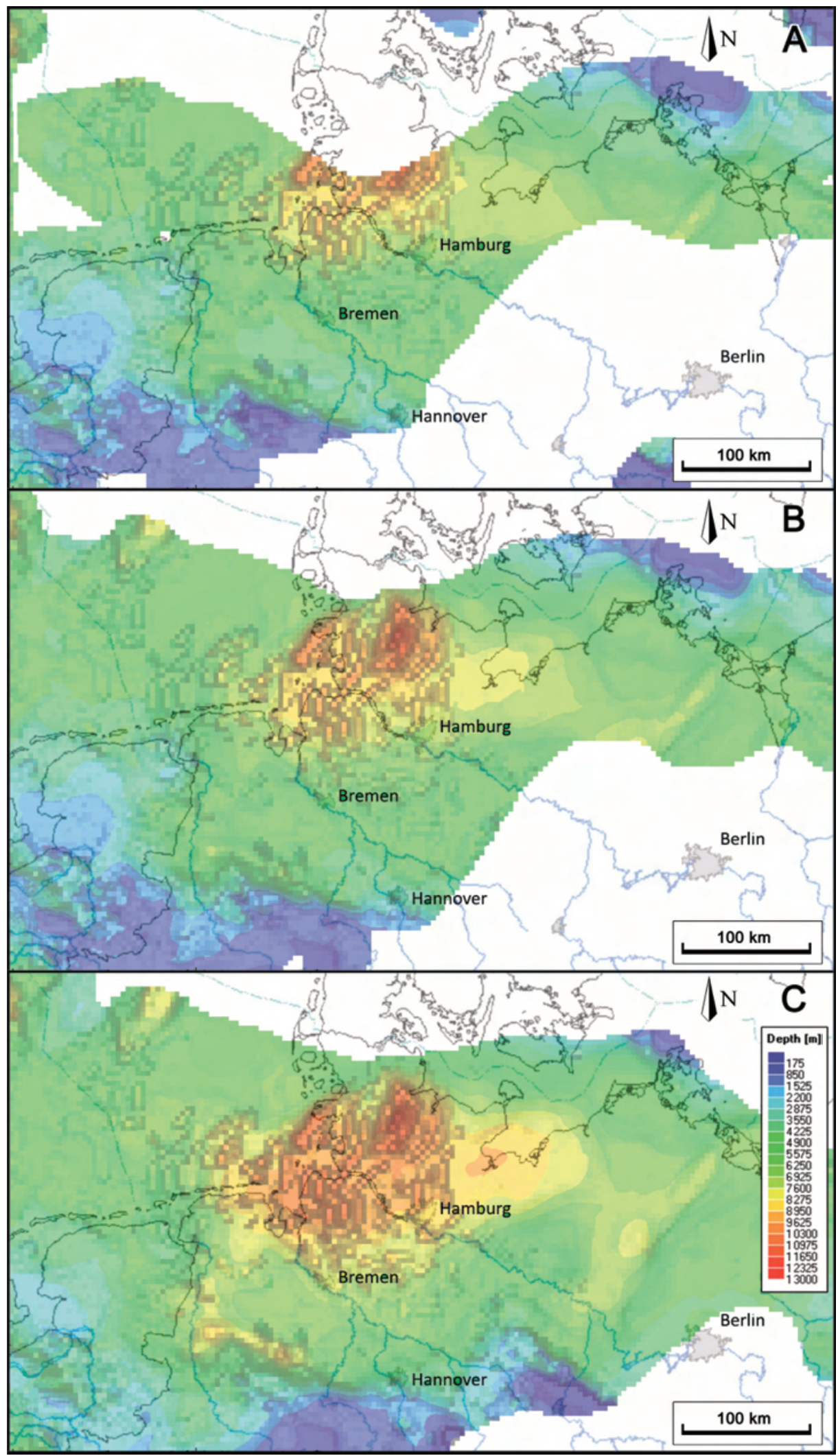

Figure 16

Depth maps for the top of Westphalian D a), top of Westphalian B b), and top of Namurian c) for the North German Basin. Data are based on a structural model by Maystrenko et al. (2010) and further data on pre-Permian thickness (Krull, 2005). 3D-PetroMod software was used for visualization and modeling. 
The overlying Upper Namurian (Namurian C) and Westphalian consist of coal-bearing strata in great thickness (up to $3000 \mathrm{~m}$ ). Marine black shales are usually quite thin (less than 10-20 $\mathrm{m}$ on average), and occur more frequently in the lower part of the sequence than in the upper part. However, clayey sediments of Westphalian A to C age up to $1000 \mathrm{~m}$ thick occur in the northeastern-most part of Germany below $5000 \mathrm{~m}$ (well Pudagla 1, island of Usedom). This sedimentary succession contains exclusively methane in porous intervals in contrast to nitrogen-dominated under- and overlying sediments, and is characterized by maturities of 1.5 to $2.5 \% \mathrm{VR}_{\mathrm{r}}$ and occasional layers with TOC contents as high as $35 \mathrm{wt} \%$ (0.5 on average; Hoth, 1997).

Of great importance for the development of gas shale plays in the basin is the present depth. A basin-wide overview on the depth of the top of the Namurian is presented in Figure 16c. In the central part of the basin (Hamburg area) the top of the Namurian is at more than $7500 \mathrm{~m}$ depth, in more marginal parts at 3500 to $7500 \mathrm{~m}$. The Namurian is quite shallow in the south and also close to the Baltic Sea, where it subcrops beneath Westphalian sediments to the northeast.

The thermal maturity of Carboniferous units differs considerably and depends mainly on maximum depth of burial (Littke et al., 2008b). Palaeo-heat flows varied within the basin but were almost always within the typical range for continental crust. Permian heat flows were probably higher, but had only a limited affect on present-day maturation because the sediments were at shallow depth then. Presentday heat flows show some variability, ranging usually between 50 and $90 \mathrm{~mW} / \mathrm{m}^{2}$ (Hurter and Haenel, 2002; Królokowski, 2006; compilation in Littke et al., 2008b). Maximum burial and maximum temperatures were reached in part of the basin in the Tertiary/Quaternary (Littke et al., 2008b), e.g. in the area of the Pompeckj Block. In contrast, other parts reached highest temperatures already in the Late Cretaceous, e.g. the Lower Saxony Basin or Mid-Polish Basin. Present-day maturity of the top Namurian is accordingly not only related to present depth. The base of the Namurian is overmature or in the gas window in almost the entire study area (Fig. 17c). The top of the Namurian is clearly less mature in the west (Netherlands area), whereas very high maturities occur in the area of the Pomeckj Block and the Lower Saxony Basin (Fig. 17).

Promising areas for finding pre-Westphalian gas have been mapped by Gerling et al. (1999a). The authors concluded that two west to east-trending ribbons can have source rock potential for gas and thus shale gas potential in the Early Namurian. The northern belt extends north of Hamburg ending in the German offshore "Duck's beak" and the southern belt from Berlin in the east westwards.

Several black shales occur in Permian strata. The Kupferschiefer at the base of the Upper Permian is known for $\mathrm{Cu}-\mathrm{Fe}-\mathrm{S}-(\mathrm{Ag})$ mineralizations, and is still exploited in
Poland today. The basinal facies is represented by a thin $(<50 \mathrm{~cm})$, TOC-rich black shale and laminated marl (Paul, 1986). However, this low thickness is a limiting factor for shale gas exploration. Organic-rich mudstones of the Stassfurt Carbonate basinal and lower slope facies $(\mathrm{Ca} 2$, Zechstein, Upper Permian) are proven source rocks for oil and gas fields in the Northeast German Basin (NEGB). South of Berlin (Fig. 1; southern Brandenburg area) the so called "Stinkschiefer" sediments of the basal Zechstein show a trend of increasing maturity from south to north, which is favorable for gas shale-similar features near the basin center. The $\mathrm{Ca} 2$ basin facies occurs below $3800 \mathrm{~m}$ depths. It has reached a minimum thermal maturity of $2.2 \% \mathrm{VR}_{\mathrm{r}}$ to generate dry thermogenic gas. In contrast the lower slope deposits occur at depths from 1250 to $3250 \mathrm{~m}$ and have oil window maturity, ranging from 0.7 to $1.0 \% \mathrm{VR}_{\mathrm{r}}$. The organic matter is a mixed type II/III kerogen, the hydrogen index ranges from 7 to $105 \mathrm{mg} \mathrm{HC} / \mathrm{g}$ rock. The low silica contents, low average TOC contents $(0.2$ to $0.8 \mathrm{wt} \%)$, and the low formation thickness, on average $6 \mathrm{~m}$, are limiting factors for the gas shale potential of the $\mathrm{Ca} 2$. However, the effective sealing by evaporites below and above the $\mathrm{Ca} 2$ may restrict expulsion of generated gas, leading to gas storage within $\mathrm{Ca} 2$ black shales (Hartwig and Schulz, 2010).

\section{COALBED METHANE}

The coalbed methane resource of the Central European Basin is associated with the coal-bearing Upper Carboniferous sequences which outcrop along the northern Variscan front from France across Belgium and Germany to Poland. The Carboniferous coal-bearing sequence consists of alternating intervals of coals, siltstones and sandstones with a total cumulative thickness of up to $3000 \mathrm{~m}$ (Krull, 2005) or even more (Drozdzewski and Wrede, 1994). These sequences have their greatest thickness the Ruhr Basin area, whereas thickness is reduced to less than $1000 \mathrm{~m}$ in the North Sea and in northeast Germany, where a small elongated area with sediments occurs (Lokhorst et al., 1998).

The cumulative thickness of coal seams is variable. It is highest in the southwest, where also the greatest thickness of Carboniferous sediments is encountered. Stratigraphically, the coal seams are concentrated in the Westphalian A and B (Fig. 8 and Fig. 18a). These intervals have also the highest contents of total organic matter (Gaschnitz, 2000, Scheidt and Littke, 1989; Fig. 18b). It should be noted that roughly one third of the total organic matter occurs in dispersed form.

In most parts of the North German Basin, Carboniferous coals occur at great depth. This fact is visualized for the top of the Westphalian B in Figure 16b. Westphalian B and the underlying Westphalian A are the two most coal-rich units within the Carboniferous sequence. These units are presently at a depth of more than $3500 \mathrm{~m}$ in most of the North German 


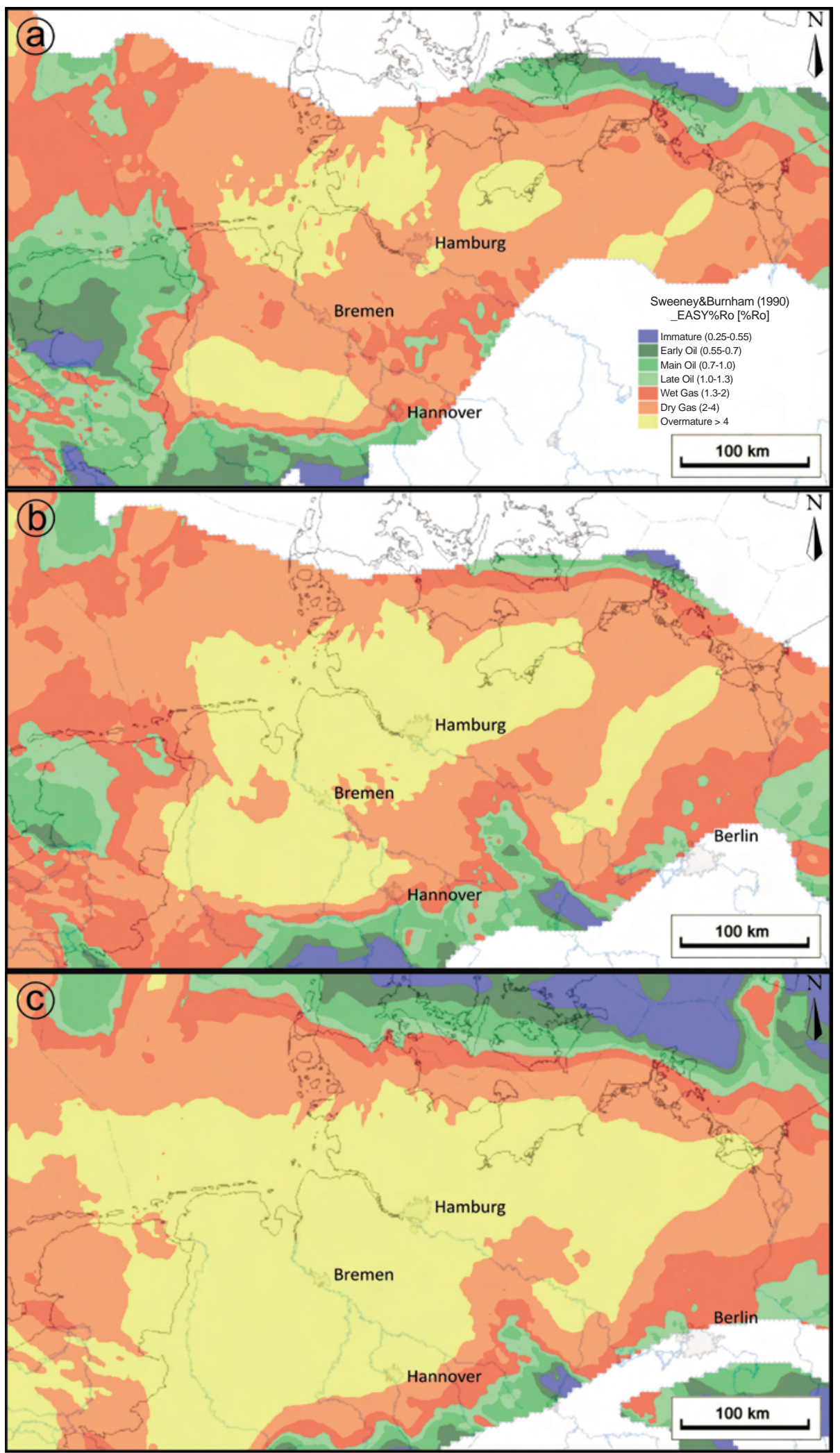

Figure 17

Thermal maturity of the top of the Westphalian B a), top of the Namurian b) and top of the Dinantian c) for the North German Basin. Data are based on a structural model by Maystrenko et al. (2010) and further data on pre-Permian thickness (Krull, 2005). Maturity was calculated based on the approach by Burnham and Sweeney (1989). Calibration is based on numerous studies for individual wells (see Littke et al., 2000 and Littke et al., 2008b and references therein). 3D-PetroMod software was used for visualization and modeling. 
Basin. Exceptions occur the western (The Netherlands) and southern (Ruhr Basin) part of the system, where the rocks are at shallower depth. Here the uppermost coal seams pertain to the Westphalian C and D the top of which is at much shallower depth than the underlying Westphalian B (Fig. 16a).

The maturity of the coal-bearing strata, e.g. of the top of the Westphalian B, extends from less than $1 \%$ vitrinite reflectance $\left(\mathrm{VR}_{\mathrm{r}}\right)$ in marginal areas to more than $4 \%$ in the Lower Saxony Basin (west of Hannover) or the Glückstadt Graben (north of Hamburg; Drozdzewski et al., Fig. 17a) where they underwent deep burial. The older coal-bearing strata are outlined in the top Namurian map (Fig. 17b). They have reached the gas generation stage almost throughout the entire basin.

As discussed above, gas contents of coal seams are not uniquely controlled by the maturity and gas generation history of the coals. In areas with important (palaeo-)tectonic activity and structural complexity, gas contents are usually highly variable (Karffanke, 1985, Freudenberg et al., 1996). This holds in particular for the bituminous coals in the Ruhr basin. Hinderfeld et al. (1990) and Gaschnitz (2000) identified five different types of vertical gas content profiles (Fig. 19): In the western part of the basin, close to the river Rhine, gas contents are generally low in the synclines $\left(<4 \mathrm{~m}^{3} / \mathrm{t}\right)$ but can reach values of $6-8 \mathrm{~m}^{3} / \mathrm{t}$ in the anticlines. The highest gas contents occur typically several hundred meters below the Permian/Mesozoic overburden. In contrast, the coals in the eastern part of the Ruhr basin are much more gas-rich. Here the highest gas contents are found within the top Carboniferous intervals, directly below the Mesozoic unconformity. A second concentration maximum occurs at somewhat greater depth. Gas contents in these intervals can reach 10 to $14 \mathrm{~m}^{3} / \mathrm{t}$ and more. The differences in gas profiles are not related to changes in coal facies and they can also not be attributed to differences in thermal maturity. The character of the overburden rocks appears to be a controlling factor. In the east, the Carboniferous sequence is directly overlain by Cretaceous and Tertiary marly and shaly sediments, including the Emscher marl. These rocks have a low permeability and appear to act as efficient cap rocks for the Carboniferous. In contrast, the overburden in the western part consists of more permeable sequences of Permian to Quaternary age with lesser sealing efficiencies.

At present, methane-rich gas is produced from several abandoned coal mines in the Ruhr district, Germany. Thielemann et al. (2004) investigated the isotopic composition of this gas which clearly differs from that of the deep conventional gas resources further north (Fig. 1) which are also (mainly) derived from Carboniferous coals. This difference has to be attributed to a significant admixture of microbial gas, which is probably much younger than the thermal gas. Similar regional occurrences of isotopically light methane have meanwhile been observed in other coal basins in Europe (Silesian Basin) and Australia (Sydney Basin). They indicate that microbial gas generation from coals might be a rather common process in sedimentary basins.

The anthracite-rank coals of the Ibbenbüren coal mine district are particularly gas-rich. Despite substantial uplift (about $4000 \mathrm{~m}$; Senglaub et al., 2006) of this horst structure the gas is still in place and is only released upon massive formation damage due to active mining and pre-drainage activities. This is indicative of the extremely low permeability of the anthracite which constitutes a typical problem in CBM production from deep Carboniferous coal seams of the North German Basin.

Gas management and utilization in the remaining coal mining areas of Central Europe are conducted on a high technological level for safety and environmental purposes. Thus over $90 \%$ of the drainage gas of the Ibbenbüren anthracite mine (see Fig. 1 for location) is captured and used for power generation. Also, the German Saar area $(200 \mathrm{~km}$ south of Köln, Fig. 1) has an extensive infrastructure of gas capture and utilization from pre- to post-mining activities. Thus, coal mine methane and abandoned mine methane still constitute the exclusive coal gas resources produced in Central Europe, while economic production from virgin coal seams has not been achieved yet.

Large-scale CBM exploration from virgin coal seams took place in the USA starting from the late 1980ies and first major attempts to exploit this resource in Europe were made in the early to mid 1990ies mainly in Germany and Poland. Thus a consortium of Conoco, Ruhrkohle AG and Ruhrgas AG drilled two exploration wells (Riet1 and Natarp1) in the Münsterland Basin (Fig. 1). The lease expired in 1998. After an intermission of more than 10 years, CBM exploration activities in Germany have been resumed with some intensity in 2009. Concessions in North Rhine-Westphalia are presently held by ExxonMobil and Queensland Gas. CBM exploration has been resumed also in other European countries, the main areas of interest being Poland (Lublin area and Upper Silesian Basin), the UK and France. The target areas of CBM exploration activities are adjacent to active or historic coal mining areas and extend towards the basin centre.

On the world level the most conspicuous development of CBM activities can be presently witnessed in Australia with an increase from essentially zero to $>8000 \mathrm{PJ}$ (petajoule) within 10 years (Baker and Slater, 2008).

Estimates of CBM resources should be considered with great caution because the technical producibility still remains a serious problem. Coalbed methane resources in the UK were estimated to be in the order of $2.9 \times 10^{12} \mathrm{~m}^{3} \mathrm{CH}_{4}$ (Jones et al., 2005). However, the limited exploratory drilling for coalbed methane in unmined areas undertaken to date has not led to commercial production - the major obstacles being low seam permeability, drilling and completion costs. Thielemann (2002) reports estimates of $3 \times 10^{12} \mathrm{~m}^{3} \mathrm{CH}_{4}$ for Germany (Tab. 1) and Poland, respectively and $1.7 \times 10^{12} \mathrm{~m}^{3}$ 


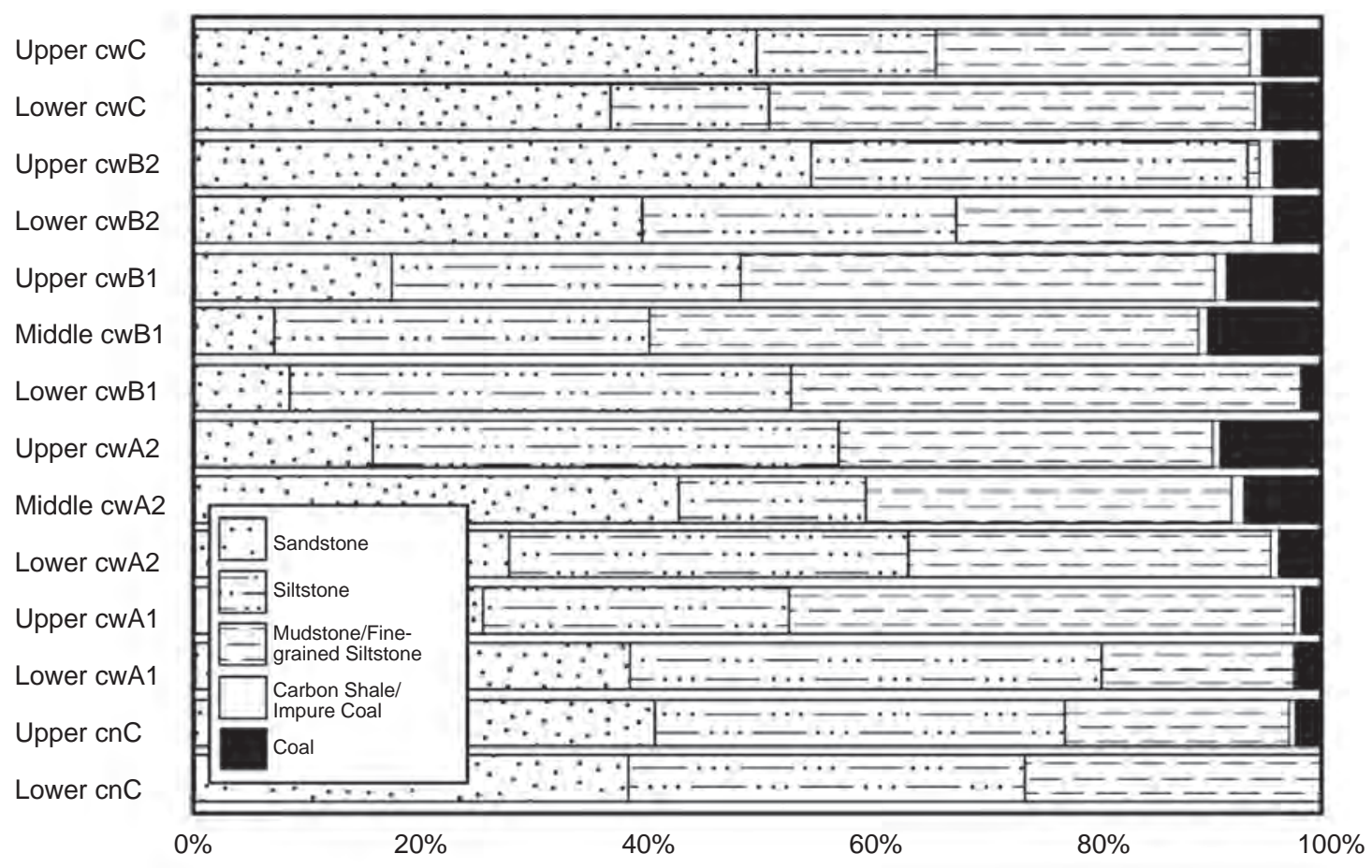

a)

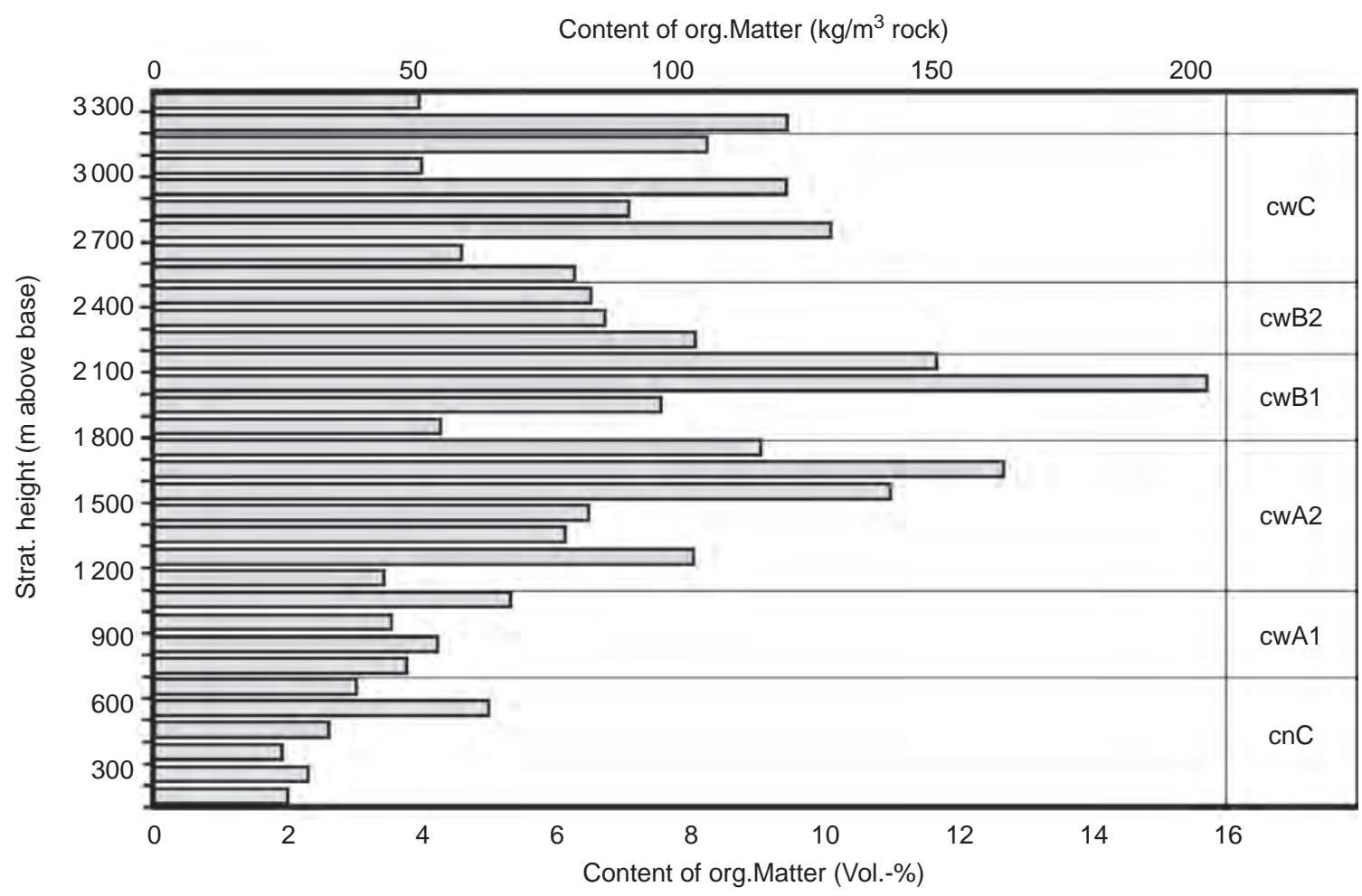

Figure 18

Distribution of lithologies in different stratigraphic units of the Carboniferous Ruhr Basin a) and content of organic matter b) (modified after Gaschnitz, 2000). Note that on average two third of the organic matter is bound in coals, whereas one third occurs dispersed in other lithologies (Scheidt and Littke, 1989). 


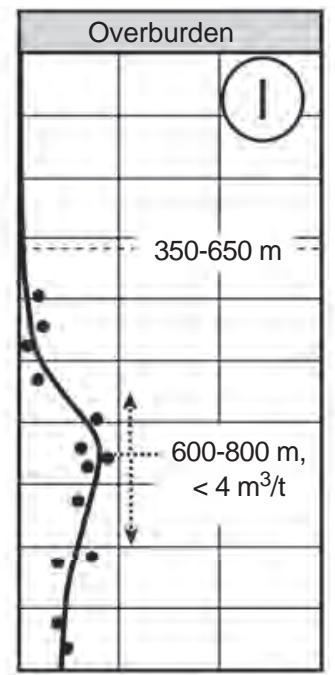

Western synclines

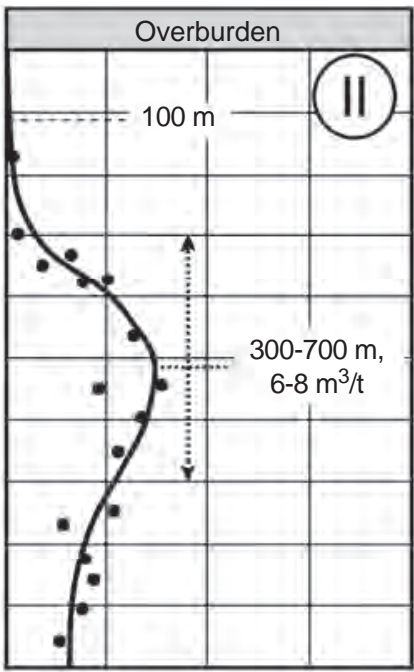

Western anticlines

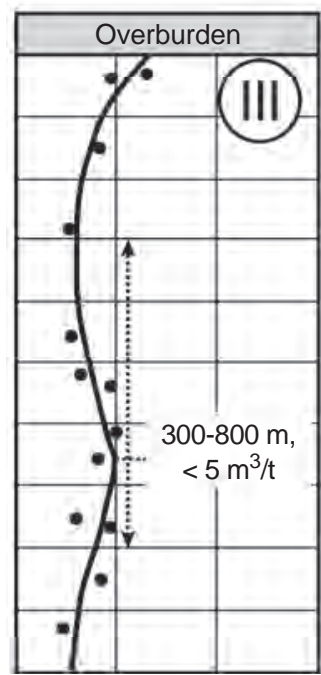

Central synclines

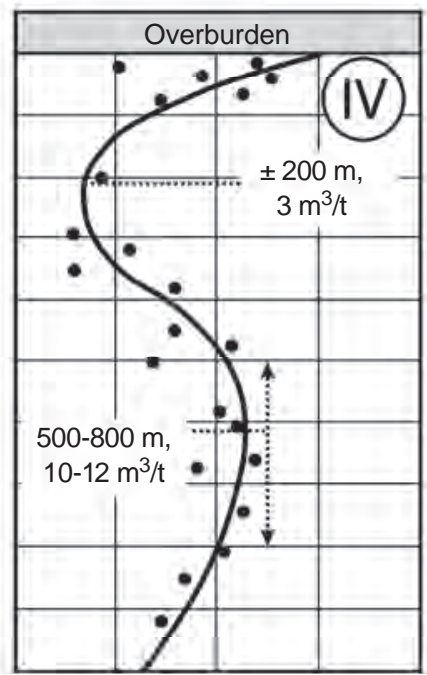

Eastern synclines

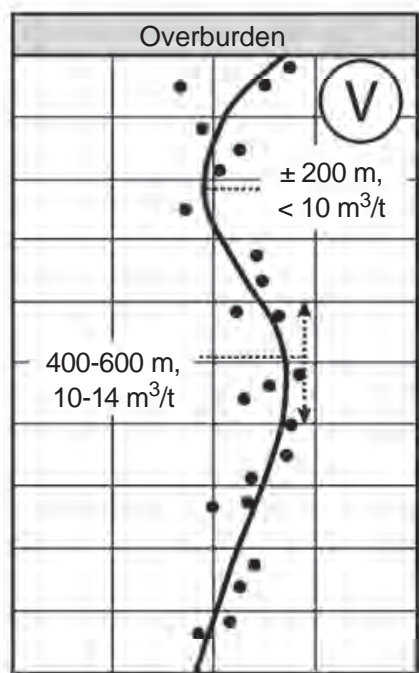

Eastern anticlines

Figure 19

Typical gas contents of coals in the Pennsylvanian (Upper Carboniferous) of the Ruhr Basin (modified after Gaschnitz, 2000).

TABLE 1

Estimated reserves of unconventional gas in Germany and Western Europe

\begin{tabular}{c|c|c|c}
\hline & Germany $^{1,3}$ & Western Europe $^{1,2}$ & Central Europe $^{4}$ \\
\hline CBM & $\begin{array}{c}500-3000 \mathrm{Gm}^{3} \\
\left(0.2-1.1 \times 10^{20} \mathrm{~J}\right)\end{array}$ & $\begin{array}{c}4 \mathrm{Gtoe} \\
\left(1.7 \times 10^{20} \mathrm{~J}\right)\end{array}$ & \\
\hline Tight gas & $\begin{array}{c}100-150 \mathrm{Gm}^{3} \\
\left(0.04-0.05 \times 10^{20} \mathrm{~J}\right)\end{array}$ & $\begin{array}{c}9 \mathrm{Gtoe} \\
\left(3.8 \times 10^{20} \mathrm{~J}\right)\end{array}$ & \\
\hline Shale gas & $?$ & $\begin{array}{c}13 \mathrm{Gtoe} \\
\left(5.4 \times 10^{20} \mathrm{~J}\right)\end{array}$ & $\begin{array}{c}>30 \mathrm{Gm}^{3} \\
\left(>0.1 \times 10^{20} \mathrm{~J}\right)\end{array}$ \\
\hline
\end{tabular}

${ }^{1}$ BGR 2009; ${ }^{2}$ Rogner (1997); ${ }^{3}$ Thielemann (2002); ${ }^{4}$ Kuusjraa (2009). CBM in Germany: mainly Upper Carboniferous coal-bearing strata (Fig. 8) in Münsterland Basin/Ibbenbüren area (see Fig. 1); Tight Gas in Germany: mainly Rotliegend (Permian) and Upper Carboniferous sandstones in Northwest German Basin (see Fig. 1) extending into the Netherlands/North Sea; Paleozoic shale gas in Germany: mainly Lower Carboniferous shales, e.g. in Münsterland Basin. Central Europe: based on Cambrian Alum Shale, Sweden, Silurian Shales, Poland, Mikulov Shale, Austria. Conversion factors: $41.868 \mathrm{GJ} /$ toe; 1 ton of oil equivalent $=$ appr. $1125 \mathrm{cubic}$ meters of natural gas (see BGR, 2009). Note that all numbers are rough estimates.

$\mathrm{CH}_{4}$ for the UK.

\section{CONCLUSIONS}

Unconventional gas resources in Central Europe have a great 
potential to provide substantial energy for the future (Tab. 1). Tight gas sandstones and especially gas shales are characterized by low permeabilities, whereas coals containing methane (CBM) have a complicated pore system consisting of large cleats and small matrix pores in the sub-nanometer range.

Tight gas sandstones occur basically in the same area and in the same formations, where also conventional reservoirs are present. Especially the Permian Rotliegend sandstones have a significant gas potential which has been proven by successful production. Frac technologies are necessary to develop these reservoirs. Changes in burial history, gas charge, sandstone facies and diagenesis greatly influence poroperm data in these sandstones.

Palaezoic organic matter-rich shales are abundant in the study area and comprise different stratigraphic intervals ranging from Cambrian to Late Permian (Zechstein). In southern Scandinavia and northern Poland, the Cambro-Ordovician Alum Shale and Silurian Shales have to be regarded as prime targets, whereas Lower Carboniferous and Namurian Shales can have a high potential in the areas further south. Besides organic matter content and thickness, variability in thermal maturity and gas generation history are key factors for developing exploration and production targets.

In Central Europe, Carboniferous coals and anthracites have variable and often high gas contents. Interestingly, in the coal mining areas this gas is a mixture of thermogenic and more recently generated microbial gas. Currently gas production is restricted to abandoned underground mines, but exploration activities have been resumed in various countries recently. Probably, permeability rather than gas content will be the limiting factor for production.

\section{ACKNOWLEDGMENTS}

We would like to thank Joyce Dietrichs, RWTH Aachen, for discussion and contribution concerning tight gas sandstone subject. Comments and suggestions by Alexandra Amann, Yves Gensterblum and Philipp Weniger on the coalbed methane section were highly appreciated. Special thanks are due to Victoria Sachse, Zoe Sobisch and Frederick Orth for their help in editing the manuscript. We also gratefully acknowledge the comments by two anonymous reviewers and François Roure on an earlier version of this manuscript.

\section{REFERENCES}

Adriasola Munoz Y., Littke R., Brix M.R. (2007) Fluid systems and basin evolution of the western Lower Saxony Basin, Germany, Geofluids 7, 335-355.
Andruleit H., Rempel H., Meßner J., Babies H.G., Schlömer S., Schmidt S., Cramer B. (2010) Nicht-konventionelles Erdgas: Weltweite Ressourcen und Entwicklungen eines "Hoffnungsträgers" unter den fossilen Energierohstoffen, Erdöl Erdgas Kohle 126, 7/8, 277-282.

Armands G. (1972) Geochemical study of Uranium, Molybdenum and Vanadium in a Swedish Alum shale, Stockholm Contr. Geol. 27, 1-148.

Baker G., Slater S. (2008) The increasing significance of coal seam gas in eastern Australia, PESA Eastern Australasian Basins Symposium III, Sydney.

Berner U., Kahl T., Scheeder G. (2010) Shale Gas Exploration Hydrocarbon Potential of Sediments of the German Wealden Basin, Erdöl-Erdgas-Kohle 126, 80-84.

BGR (2009) Energierohstoffe 2009. Reserven, Ressourcen, Verfügbarkeit, Tabellen, BGR, http://www.bgr.bund.de/cln_109/ nn_330718/DE/Themen/Energie/Downloads/Energierohstoffe__20 09__gesamt,templateId=raw, property=publicationFile.pdf/Energier ohstoffe_2009_gesamt.pdf

Bond D., Wignall P.W., Racki G. (2004) Extent and duration of marine anoxia during the Frasnian-Famennian (Late Devonian) mass extinction in Poland, Germany, Austria and France, Geol. Mag. 141, 2, 173-193.

Breitkreuz C., Geissler M., Schneider J., Kiernowski H. (2008) Basin initiation: volcanism and sedimentation, in Dynamics of complex intracontinental basins. The Central European Basin System, Littke R., Bayer U., Gajewski D., Nelskamp S. (eds), SpringerVerlag, Berlin-Heidelberg, pp. 125-153.

Buchardt B. (1999) Gas Potential of the Cambro-Ordovician Alum Shale in Southern Scandinavia and the Baltic Region, in The Search for Deep Gas Selected, Whiticar M.J., Faber E. (eds), Geol. Jahrb. Reihe D 107, 9-24.

Buchardt B., Nielsen A.T., Schovsbo N.H. (1997) Alun Skiferen i Skandinavien, Geol. Tidsskrift 3, 1-30.

Burnham A.K., Sweeney J.J. (1989) A chemical kinetick model of vitrinite maturation and reflectance, Geochim. Cosmochim. Acta 53, 2649-2657.

Cameron T.D.J. (1993) Carboniferous and Devonian of the Southern North Sea, in Lithostratigraphic Nomenclatur of the U.K. North Sea, British Geol. Surv. and U.K. Offshore Operations Assoc. 91.

Cook T. (2003) Calculation of Estimated Ultimate Recovery for wells in continuous-type oil and gas accumulations of the UintaPiceance Province, Int. J. Coal Geol. 56, 1-2, 39-44.

Curtis J.B. (2002) Fractured shale-gas systems, AAPG Bull. 86, 11, 1921-1938.

Drozdzewski G., Wrede V. (1994) Faltung und Bruchtektonik Analyse der Tektonik im Subvariscikum, Fortschr. Geol. Rhld. u. Westf. 38, 7-187.

Drozdzewski G., Henscheid S., Hoth P., Juch D., Littke R., Vieth A., Wrede V. (2009) The pre-Permian of NW-Germany - Structure and coalification map, Z. Dt. Ges. Geowiss. 160, 2, 159-172.

Durham L.S. (2010) Poland Silurian shale ready for action, AAPG Expl.31, 2, 14-18.

Dyni J.R. (2006) Geology and resources of some world oil-shale deposits, U.S. Geol. Surv., Scientific Investigations Report, 2005-5294, http://pubs.usgs.gov/sir/2005/5294/pdf/sir5294_508.pdf.

Freudenberg U., Lou S., Schlüter R., Schütz K., Thomas K. (1996) Main factors controlling coalbed methane distribution in the Ruhr district, Germany, in Coalbed methane and coal geology, Gayer R., Harris I. (eds), Geol. Soc. Spec. Publ. 109, 67-88.

Gaschnitz R. (2000) Gas genese und Gasspeicherung im flözführenden Oberkarbon des Ruhr-Beckens, PhD Thesis, RWTH Aachen University. 
Gaupp R., Baunack C., Pudlo D., Solms M., Trappe H., SchubartEngelschall J., Samiee R., Littke R., Schwarzer D., Oncken O., Krawczyk C.M., Tanner D. (2005) Paleo Oil- and Gasfields in the Rotliegend of the North German Basin: effects upon hydrocarbon reservoir quality, DGMK-Forschungsbericht 593, 8, 1-242.

Gaupp R., Möller P., Lüders V., di Primio R., Littke R. (2008) Fluids in sedimentary basins: an overview, in Dynamics of Complex Intracontinental Basins. The Central European Basin System, Littke R., Bayer U., Gajewski D., Nelskamp S. (eds), Springer, Berlin, pp. 345-359.

Gedenk R., Hedemann H.A., Rühl W. (1964) Obekarbongase, ihr Chemismus und ihre Beziehungen zur Steinkohle, Congres. Av. Etudes Stratigr. Géol. Carbonifère, C.R. Paris 2, 431-450.

Geluk M.C. (2005) Stratigraphy and tectonics of Permo-Triassic basins in the Netherlands and surrounding areas, $\mathrm{PhD}$ Thesis, University of Utrecht.

Gerling P., Kockel F., Krull P. (1999a) The HC Potential of preWestphalian sediments in the North German Basin - A Synthesis, DGMK-Forschungsbericht 433, 107.

Gerling P., Geluk M.C., Kockel F., Lokhorst A., Lott G.K., Nicholson R.A. (1999b) NW European Gas Atlas - new implications for the Carboniferous gas plays in the western part of the Southern Permian Basin, in Petroleum Geology of Northwest Europe: Proceedings of the Fifth Conference, Fleet A.J., Boldy S.A.R. (eds), Geol. Soc., London, pp. 799-808.

Hadro J. (2009) Shale-gas potential in Poland, EGU General Assembly 2009, Geophys. Res. Abstr. 11.

Haines L. (ed) (2005) Tight Gas. Supplement to Oil and Gas Investor, March, http://www.oilandgasinvestor.com/pdf/ Tight\%20Gas.pdf.

Hamblin A.P. (2006) The "shale gas" concept in Canada: a preliminary inventory of possibilities, Geol. Surv. Can., Open File Report 5384,108

Hartwig A., Schulz H.-M. (2010) Applying classical shale gas evolution concepts to Germany - Part I: The basin and slope deposits of the Stassfurt Carbonate (Ca2, Zechstein, Upper Permian) in Brandenburg (Germany), Chem. Erde - Geochem. 70, 77-91.

Hickey J.J., Henk B. (2007) Lithofacies summary of the Mississippian Barnett Shale, Mitchell 2 T.P. Sims well, Wise County, Texas, AAPG Bull.91, 4, 437-443.

Hildenbrand A. (2003) Fluid Transport Processes in Mudstones, $P h D$ Thesis, RWTH Aachen University.

Hildenbrand A., Krooss B.M., Busch A., Gaschnitz R. (2006) Evolution of methane sorption capacity of coal seams as a function of burial history - a case study from the Campine Basin, NE Belgium, Int.J. Coal Geol. 66, 179-203.

Hill R.J., Zhang E., Katz B.J., Tang Y. (2007) Modeling of gas generation from the Barnett Shale, Fort Worth Basin, Texas, $A A P G$ Bull.91, 4, 501-521.

Hinderfeld G., Kunz E., Opahle M., Stengel H. (1990) Die Gasführung des Ruhrkarbons in ihrer räumlichen Verteilung und Entstehung zur Prognose der Ausgasung, in DMT-Berichte aus Forschung und Entwicklung 14, DMT, Essen.

Hoffmann N., Jödicke H., Gerling P. (2001) The distribution of PreWestphalian source rocks in the North German Basin - Evidence from magnetotelluric and geochemical data, Neth. J. Geosci. 80, 1, $71-84$.

Holditch S.A. (2006) Tight Gas Sands, J. Petrol. Technol. 58, 86-93. Horsfield B., Bharati S., Larter S.R., Leistner F., Littke R., Schenk H.J., Dypvik H. (1992) On the atypical petroleum-generating characteristics of alginite in the Cambrian Alum Shale, in Early Organic Evolution: Implications for Mineral and Energy, Schidlowski M., Golubic S., Kimberley M.M. (eds), Springer, Berlin.

Hoth P. (1997) Fazies und Diagenese von Präperm-Sedimenten der Geotraverse Harz-Rügen, Schriftenr. Geowissen. 4, 1-139.
Hurter S., Haenel R. (eds) (2002) Atlas of geothermal resources in the European Community, Austria and Switzerland, European Commission, Publ. EUR 17811.

Joachimski M.M., Ostertag-Henning C., Pancost R.D., Strauss H., Freeman K.H., Littke R., Damsté J.S.S., Racki G. (2001) Water column anoxia, enhanced productivity and concomitant changes in $\delta^{13}$ $\mathrm{C}$ and $\delta^{34} \mathrm{~S}$ across the Frasnian- Famennian boundary (KowalaHoly Cross Moutains/Poland), Chem. Geol. 175, 109-131.

Jones N.S., Holloway S., Creedy D.P., Garner K. (2005) Can UK coal resources contribute to a gas renaissance? Geol. Soc., London, Petroleum Geology Conference Series 6, 715-722.

Jordan H., Koch J. (1979) Inkohlung der Unterkarbon- und Eifelschichten im Nordwestharz und ihre Ursachen, Geol. Jb. A51, 39-55.

Joubert J.I., Grein C.T., Bienstock D. (1974) Effect of moisture on the methane capacity of American coals, Fuel 53, 3, 186-191.

Karffanke H. (1985) Gasinhalt der Flöze der Explorationsbohrungen der Bergbau AG Lippe, Glückauf-Forschungsh. 49, 38-47.

Koehler M. (2006) Rotliegend „Tight Gas“ Germany. A Development with a Mutiple Hydraulically Fractures Horizontal Well: Project Leer Z4, Gaz de France Produktion Exploration Deutschland GmbH, http://www.nlog.nl/resources/Workshop_Tight Gas/ 08_Koehler_GDFandPEG_-_The_Leer_Z4_Case_Study.pdf.

Kombrink H. (2008) The Carboniferous of the Netherlands and surrounding areas; a basin analysis, in Geologica Ultraiectina, Universiteit Utrecht, 294, ISBN: 978-90-5744-160-8.

Królokowski C. (2006) Crustal-scale complexity of the contact zone between the Paleozoic Platform and the East European Craton in the NW Poland, Geol. Quart. 50, 1, 33-42.

Krebs W. (1978) Aspekte einer potentiellen KohlenwasserstoffFührung in den devonischen Riffen Nordwestdeutschlands, Erdöl Erdgas Zeitschrift 1, 15-25.

Krooss B.M., van Bergen F., Gensterblum Y., Siemons N., Pagnier H.J.M., David P. (2002) High-pressure methane and carbon dioxide adsorption on dry and moisture-equilibrated Pennsylvanian coal, Int. J. Coal Geol. 51, 69-92.

Krooss B.M., Friberg L., Gensterblum Y., Hollenstein J., Prinz D., Littke R. (2005) Investigation of the pyrolytic liberation of molecular nitrogen from Paleozoic sedimentary rocks, Int. J. Earth Sci. 94 5-6, 1023-1038.

Krooss B.M., Plessen B., Machel H.G., Lüders V., Littke R. (2008) Origin and distribution of non-hydrocarbon gases, in Dynamics of Complex Intracontinental Basins - The Central European Basin System, Littke R., Bayer U., Gajewski D., Nelskamp S. (eds), Springer, Berlin, pp. 433-457.

Krooss B.M., Amann A., Gensterblum Y., Han F., Littke R., Weniger P. (2010) Gas Transport and Sorption Processes in Coals and Shales: New Insights and Concepts from Laboratory Experiments. Search and Discovery Article \#110127 (2010) Posted June 14, 2020 (http://www.searchanddiscovery.com/documents/ 2010/110127krooss/ndx_krooss.pdf).

Krull P. (2005) 1 Einführung. 1.2 Paläogeographischer Rahmen, Stratigraphie von Deutschland V. Das Oberkarbon (Pennsylvanium) in Deutschland, Dtsch. Stratigr. Kommission 254, 13-24.

Kuuskraa V.A. (2009) Worldwide gas shales and unconventional gas: a status, report, Advanced Resources International, Inc. Arlington, VA USA, $26 \mathrm{p}$.

Laubach S.E., Marrett R.A., Olson J.E., Scott A.R. (1998) Characteristics and origins of coal cleat: A review, Int. J. Coal Geol. 35, 1-4, 175-207.

Law B.E., Curtis J.B. (2002) Introduction to Unconventional Petroleum Systems, AAPG Bull. 86, 11, 1851-1852. 
Lazauskiene J., Sliaupa S., Musteikis P., Brazauskas A. (2003) Sequence stratigraphy of the Baltic Silurian succession: Tectonic control on the foreland infill, Geol. Soc. Lond. Spec. Publ. 208, 95-115.

Levine J.R. (1991) The impact of oil formed during coalification on generation and storage of natural gas in coalbed reservoir systems, 3rd Coalbed Methane Symp. Proc., Tuscaloosa, AL, pp. 307-315.

Liermann N., Jentsch M. (2003) Tight-Gas-Reservoir - Erdgas für die Zukunft, Erdöl Erdgas Kohle 119, 7-8, 270-273.

Littke R., Leythaeuser D. (1993) Migration of oil and gas in coals. Hydrocarbons from Coal, Law B.E., Rice D.D. (eds), Amer. Ass. Petr. Geol.Stud. Geol. 38, 219-236.

Littke R., Büker C., Hertle M., Karg H., Stroetmann-Heinen V., Oncken O. (2000) Heat flow evolution, subsidence and erosion in the Rheno-Hercynian orogenic wedge of central Europe, in Orogenic Processes: Quantification and Modelling in the Variscan Belt, Franke W., Haak V., Oncken O., Tanner D. (eds), Geol. Soc. London 179, 231-255.

Littke R., Bayer U., Gajewski D., Nelskamp S. (2008a) Dynamics of complex intracontinental basins. The example of the Central European Basin System, Springer-Verlag, Berlin-Heidelberg.

Littke R., Scheck-Wenderoth M., Brix M.R., Nelskamp S. (2008b) Subsidence, inversion and evolution of the thermal field, in Dynamics of complex intracontinental basins. The Central European Basin System, Littke R., Bayer U., Gajewski D., Nelskamp S. (eds), Springer-Verlag, Berlin-Heidelberg, pp. 125-153.

Lokhorst A., Adlam K., Brugge J.V.M., David P., Diapari L., Fermont W.J.J., Geluk M., Gerling P., Heckers J., Kockel F., Kotarba M., Laier T., Lott G.K., Milaczewski E., Milaczewski L., Nicholson R.A., Platen F.V., Pokorski J. (1998) NW European Gas Atlas Composition and Isotope Ratios of Natural Gases, CD-ROM, Nederlands Inst. voor Toegepaste Geowetenschappen TNO, Haarlem.

Lutz M., Kaasschieter J.P.H., van Wijhe D.H. (1975) Geological factors controlling Rotliegend gas accumulations in the mid European Basin, Proceed. 9th World Petrol. Cong. Tokyo 2, Appl. Sci. Publ. Ltd., 93-103, London.

Maystrenko Y., Bayer U., Scheck-Wenderoth M. (2010) Structure and Evolution of the Central European Basin System according to 3D modeling, DGMK-Forschungsbericht 577-2/2, 90 p.

Mingram B., Hoth P., Lüders V., Harlov D. (2005) The significance of fixed ammonium in Paleozoic sediments for the generation of nitrogen-rich natural gases in the North German Basin, Int. J. Earth Sci. 94, 1010-1022.

Muntendam-Bos A.G., Wassing B.B.T., ter Heege J.H., van Bergen F., Schavemaker Y.A., van Gessel S.F., de Jong M.L., Nelskamp S., van Thienen-Visser K., Guasti E., van den Belt F.J.G., Marges V.C. (2009) Inventory non-conventional gas, TNO report, TNO034-UT-2009-00774/B, 188 p., 5 App.

Nielsen A.T., Schovsbo N.H. (2007) Cambrian to basal Ordovician lithostratigraphy in southern Scandinavia, Bull. Geol.Soc. Den. 53, 47-92.

Oncken O., von Winterfeld C., Dittmar U. (1999) Accretion of a rifted margin: the late Paleozoic Rhenohercynian fold and thrust belt (Middle European Variscides), Tectonics 18, 75-91.

Pashin J.C. (2004) Cyclothems of the Black Warrior Basin in Alabama: eustatic snapshots of foreland basin tectonism, in CoalBearing Strata: Sequence Stratigraphy, Paleoclimate and Tectonics, Pashin J.C., Gastaldo R.A. (eds), Am. Ass. Petr. Geol. Stud. Geol. 51, 199-218.

Paul J. (1986) Environmental analysis of basin and schwellen facies in the lower Zechstein of Germany, Geol. Soc. London Spec. Publ. 22, 143-147.

Poprawa P., Sliaupa S., Stephenson R.A., Lazauskiene J. (1999) Late Vendian-Early Paleozoic tectonic evolution of the Baltic Basin: regional implications from subsidence analysis, Tectonophysics 314, 1-3, 219-239.
Prinz D., Littke R. (2005) Development of the micro- and ultramicroporous structure of coals with rank as deduced from the accessibility to water, Fuel 84, 12-13, 1645-1652.

Prinz D. (2004) Die Porenstruktur von Kohlen, PhD Thesis, RWTH Aachen University.

Pusch G., Gaupp R., Liermann N. (2005) Integrated Research Contributions for Screening the Tight Gas Potential in the Rotliegendes Formation of North- Germany, Oil Gas - Eur. Mag. 31, 4, 187-193.

Richwien J., Schuster R., Teichmüller R., Wolburg J. (1963) Überblick über das Profil der Bohrung Münsterland 1, in Fortschritte in der Geologie von Rheinland und Westfalen. Die Aufschlussbohrung Münsterland 1, Andres J., Arnold H., Beeg H. (eds), Fortschr. Geol. Rhld. u. Westf. 11, 9-18, Krefeld.

Ricken W., Schrader S., Oncken O., Plesch A. (2000) Turbidite basin and mass dynamics related to orogenic wedge growth: the Rheno-Hercynian case, in Orogenic Processes: Quantification and Modelling in the Variscan Belt, Franke W., Haak V., Oncken O., Tanner D. (eds), Geol.Soc. Spec. Publ. 179, 257-280.

Riquier L., Tribovillard N., Averbuch O., Devleeschouwer X., Riboulleau A. (2006) The Late Frasnian Kellwasser horizons of the Harz Mountains (Germany): Two oxygen-deficient periods resulting from different mechanisms, Chem. Geol. 233, 1-2, 137-155.

Rogner H.-H. (1997) An assessment of world hydrocarbon resources, Annu. Rev. Energ. Env. 22, 217-262.

Scheidt G., Littke R. (1989) Comparative organic petrology of interlayered sandstones, siltstones, mudstones and coals in the Upper Carboniferous Ruhr basin, northwest Germany, and their thermal history and methane generation, Geol. Rundsch. 78, 375-390.

Schindler E. (1992) Kellwasser Horizons, in Organic Carbon-rich Pelitic Sediments in the Federal Republic of Germany, Zimmerle W., Stribrny B. (eds), Courier Forschungsinstitut Senckenberg 152, 56-58, Frankfurt.

Schöner R., Gaupp R. (2005) Contrasting red bed diagenesis. The southern and northern margin of the Central European Basin, Int. J. Earth Sci. 94, 897-916.

Schovsbo N.H. (2002) Uranium enrichment shorewards in black shales: A case study from the Scandinavian Alum Shale, Geol. Foeren. Stockholm Foerh. 124, 2, 107-115.

Schovsbo N.H. (2003) The geochemistry of Lower Paleozoic sediments deposited on the margins of Baltica, Bull. Geol.Soc.Den. 50, 1,11-27.

Schretzenmayr S. (2004) Erdöl und Erdgas, in Geologie von Mecklenburg-Vorpommern, Katzung G. (ed), Schweizerbart'sche Verlagsbuchhandlung, Stuttgart, pp. 451-458.

Schwarzer D., Littke R. (2007) Petroleum generation and migration in the "Tight Gas" area of the German Rotliegend natural gas play: a basin modelling study, Petrol. Geosci. 13, 1, 37-62.

Senglaub Y., Littke R., Brix M.R. (2006) Numerical modeling of burial and temperature history as an approach for an alternative interpretation of the Bramsche anolmaly, Lower Saxony Basin, Int. J. Earth Sci. 95, 204-224.

Shanley K.W., Cluff R.M., Robinson J.W. (2004) Factors controlling prolific gas production from low-permeability sandstone reservoirs: Implications for resource assessment, prospect development, and risk analysis, AAPG Bull. 88, 8, 1083-1121.

Siegmund H., Trappe J., Oschmann W. (2002) Sequence stratigraphic and genetic aspects of the Tournaisian "Liegender Alaunschiefer" and adjacent beds, Int . J. Earth Sci. 91, 934-949.

Snäll S. (1988) Mineralogy and maturity of the alum shales of south-central Jämtland, Sweden, Geol. Sur. Swed. C818. 
Stollhofen H., Bachmann G.H., Barnasch J., Bayer U., Beutler G., Franz M., Kästner M., Legler B., Mutterlose J., Radies D. (2008) Upper Rotliegend to Early Cretaceous basin development, in Dynamics of complex intracontinental basins. The Central European Basin System, Littke R., Bayer U., Gajewski D., Nelskamp S. (eds), Springer-Verlag, Berlin-Heidelberg, pp. 181-210.

Sweeney J.J., Burnham A.K. (1990) Evaluation of a simple model of vitrinite reflectance based on chemical kinetics, $A A P G$ Bull. 74, 1559-1570.

Teichmüller M., Teichmüller R., Bartenstein H. (1979) Inkohlung und Erdgas in Nordwestdeutschland. Eine Inkohlungskarte der Oberfläche des Oberkarbons, Fortschr. Geol. Rhld. u. Westf. 27.

Thickpenny A. (1984) The sedimentology of the Swedish Alum Shales, in Fine-grained Sediments: Deep-water Processes and Facies, Stow D.A.V., Piper D.J.W. (eds), Geol. Soc. London Spec. Publ. 15, 511-525.

Thielemann T. (2002) Kohleflözgas in Deutschland, Commodity Top News 17.

Thielemann T., Cramer B., Schippers A. (2004) Kohleflözgas im Ruhrbecken: Fossil oder erneuerbar? DGMK-Tagungsbericht, Fachbereich Aufsuchung und Gewinnung, Celle, pp. 449-459.

Uffmann A.K., Bruns B., Jurisch A., Littke R. (2010) Dynamics of the Central European Basin System (CEBS): Large scale Paleozoic petroleum systems models of the North German Basin, DGMK Research Report, 577-2/3, 129 p. van Buggenum J.M., den Hartog Jager D.G. (2007) Silesian, in Geology of the Netherlands, Wong Th.E., Batjes D.A.J., de Jager J. (eds), Royal Netherlands Academy of Arts and Sciences, pp. 43-62.

Voigt T., Reicherter K., von Eynatten H., Littke R., Voigt S., Kley J. (2008) Sedimentation during basin inversion, in Dynamics of complex intracontinental basins. The Central European Basin System, Littke R., Bayer U., Gajewski D., Nelskamp S. (eds), Springer-Verlag, Berlin-Heidelberg, pp. 211-232.

Williams P. (2009) Euro Shales, Oil Gas Inv., 57-59.

Yahi N., Schaefer R.G., Littke R. (2001) Petroleum generation and accumulation in the Berkine basin, eastern Algeria, AAPG Bull. 85, 8, 1439-1467.

Zdanaviciutė O., Lazauskiene J. (2004) Hydrocarbon migration and entrapment in the Baltic Syneclise, Org. Geochem. 35, 4, 517-527.

Zdanaviciute O., Lazauskiene J. (2007) The petroleum potential of the Silurian succession in Lithuania, J. Petrol. Geol. 30, 4, 325-337.

Ziegler A.M. (1990) Phytogeographic patterns and continental configurations during the Permian Period, Geol. Soc.London Mem. 12, 363-379. or distributed for profit or commercial advantage and that copies bear this notice and the full citation on the first page. Copyrights for components of this work owned by others than IFP Energies nouvelles must be honored. Abstracting with credit is permitted. To copy otherwise, to republish, to post on servers, or to redistribute to lists, requires prior specific permission and/or a fee: Request permission from Information Mission, IFP Energies nouvelles, fax. +331475270 96, or revueogst@ifpen.fr. 